\title{
Light-Actuated Resorcin[4]arene Cavitands
}

Víctor García-López ${ }^{\mathrm{a}, \dagger}$, Jovana V. Milić ${ }^{\mathrm{a}, \dagger}{ }^{\dagger}$, Michal Zalibera ${ }^{\mathrm{b}}$, Dmytro Neshchadin ${ }^{\mathrm{c}}$, Martin Kuss-Petermann ${ }^{\mathrm{d}}$, Laurent Ruhlmann ${ }^{\mathrm{e}}$, Julia Nomrowski ${ }^{\mathrm{d}}$, Nils Trapp ${ }^{\text {a }}$, Corinne Boudon ${ }^{\mathrm{e}}$, Georg Gescheidt $^{\mathrm{c}}$, Oliver S. Wenger ${ }^{\mathrm{d}}$, François Diederich ${ }^{\mathrm{a}, *}$

$\dagger$ Equal contribution

${ }^{\text {a }}$ Laboratory of Organic Chemistry, ETH Zurich, HCI, Vladimir-Prelog-Weg 3, 8093 Zurich, Switzerland

${ }^{\mathrm{b}}$ Institute of Physical Chemistry and Chemical Physics, Slovak University of Technology, Radliského 9, 81237 Bratislava, Slovakia

c Institute of Physical and Theoretical Chemistry, NAWI Graz, Graz University of Technology, Stremayrgasse 9/Z2, 8010 Graz, Austria

${ }^{\mathrm{d}}$ Department of Chemistry, University of Basel, St, Johanns-Ring 19, 4056 Basel, Switzerland

e Université de Strasbourg, Laboratoire d'Electrochimie et de Chimie Physique du Corps Solide, Institut de Chimie de Strasbourg, 4 rue Blaise Pascal, CS 90032, 67081 Strasbourg, France

\section{Abstract}

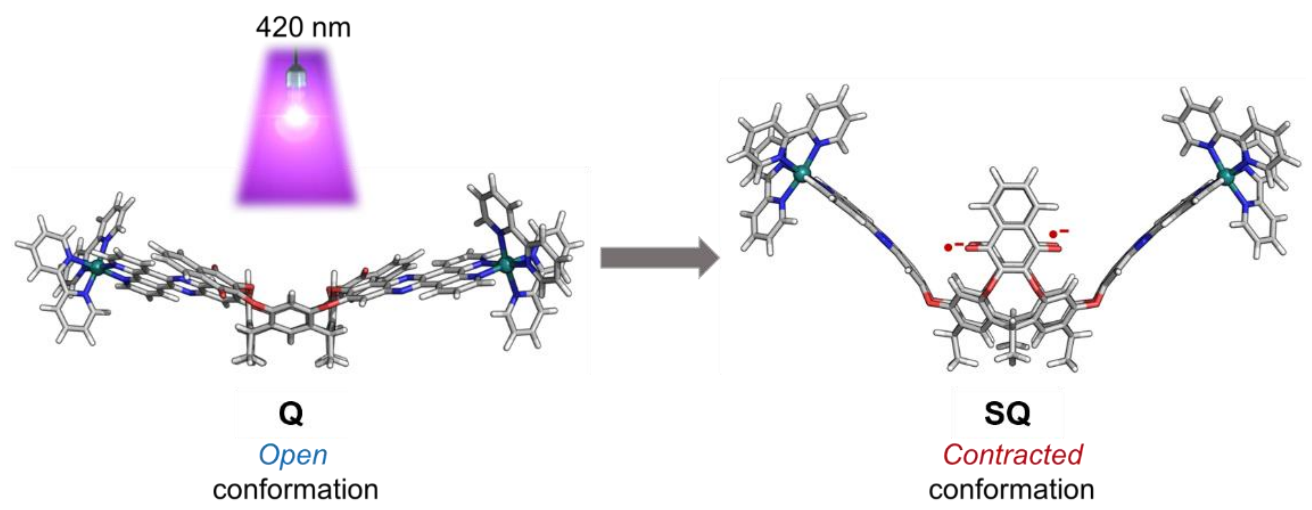

A light-actuated resorcin[4]arene cavitand equipped with two quinone $(\mathbf{Q})$ and two opposite $\mathrm{Ru}(\mathrm{II})$-based photoredox-active walls was synthesized and investigated. The cavitand is capable of switching from an open to a contracted conformation upon reduction of the $\mathbf{Q}$ to the $\mathbf{S Q}$ radical dianion state by intramolecular photoinduced electron transfer. The molecular switch was investigated by cyclic and rotating disc voltammetry, UV-Vis-NIR spectroelectrochemistry, transient absorption, and EPR spectroscopy. This study provides the basis for the development of future photoredox switches and molecular actuating nanodevices.

Keywords:

Light-actuated cavitands, resorcin[4]arene switches, photoredox switches, semiquinones 


\section{Introduction}

Resorcin[4]arene cavitands are promising systems for the development of the next generation of molecular grippers due to their ability to switch between an open and a closed conformation. $^{[1]}$ While the closed conformation can capture guest molecules in its cavity, the switch to the open could mediate their release. The switching and gripping ability of different resorcin[4]arene cavitands has been previously demonstrated using stimuli such as changes in $\mathrm{pH},{ }^{[2]}$ temperature ${ }^{[3,4]}$ metal ion concentration, ${ }^{[5]}$ and redox reactions. ${ }^{[6-8]}$ In addition to these activation methods, light-activated cavitands are highly desired because light allows for switching the molecules with specific spatio-temporal control and without the need of individual activation $^{[9,10]}$ (e.g. by tunneling electrons from the STM tip), ${ }^{[1]}$ direct contact (e.g. through electrodes in an electrochemical cell $)^{[12]}$ or the need of adding reactants during the operation of the switch.

The latest attempt to develop light-activated molecular grippers was based on resorcin[4]arene cavitands containing two unreactive quinoxaline $(\mathrm{Qx})$ walls and two redox-active quinone (Q) walls (Fig. 1a). ${ }^{[13,14]}$ By reducing the quinone (Q) to the semiquinone (SQ) state by means of intermolecular photoinduced electron transfer (PET) from $\left[\mathrm{Ru}(\mathrm{bpy})_{3}\right]^{2+}$ as a photocatalyst, switching towards the closed conformation was achieved. However, this system required the diffusion and contact of the photocatalyst and the cavitand for the photoredox process to take place, as well as the use of triethyl amine $\left(\mathrm{Et}_{3} \mathrm{~N}\right)$ as sacrificial electron donor to regenerate the catalyst and increase the concentration of the SQ. Although this work was a breakthrough that led the development of one of the first examples of a photoredox-switchable cavitands, while establishing of the methodology for monitoring the switching in the SQ state, it does not fulfill the ultimate goal of using light as the only external stimuli without resorting to external catalysts.

We envisage that the switching from the open to the closed conformation could be achieved by intramolecular PET to provide the basis for the development of light-actuated cavitands, which rely on the direct interaction between the cavitand and light as the only external stimulus. Towards this goal, we herein present the synthesis of a new resorcin[4] arene cavitand 1 with two quinone (Q) walls as electron acceptor units, and two $\mathrm{Ru}^{\mathrm{II}}$-based photoredox catalysts installed directly within the cavitand backbone (Fig. 1b). We demonstrate the switching from the open to a contracted conformation upon electrochemical and chemical reduction of the $\mathbf{Q}$ to the $\mathbf{S Q}$ state, as well as upon photoexcitation. 


\section{Results and Discussion}

\subsection{Molecular Design}

Inspired by the previous intermolecular photoredox cavitands ${ }^{[13-14]}$ and the vast number of molecular machines driven by intramolecular PET, ${ }^{[10]}$ the incorporation of a suitable $\left[\mathrm{Ru}(\mathrm{bpy})_{3}\right]^{2+}-$ based photocatalyst into the resorcin[4]arene cavitand walls was envisioned. For this purpose, either quinone- or quinoxaline-based cavitand wall required functionalization with the dye. In the case where $\mathrm{Ru}{ }^{\mathrm{II}}$ complex is installed onto the quinone wall, an ultrafast electron transfer followed by charge recombination are expected. ${ }^{[15,16]}$ Moreover, the quinone as a ligand of the $\mathrm{Ru} \mathrm{u}^{\mathrm{II}}$ complex would change its photoredox properties. Indeed, the electrochemical investigation of model system 3 comprising the $\mathrm{Ru}^{\mathrm{II}}$-quinone-based wall (synthesis and characterization are detailed in Section S1-S4 of the Supporting Information) revealed a driving force 10 times higher than for cavitand 1, while the SQ state could not be detected during light excitation due to the ultra-fast charge recombination, rendering such system unsuitable for the design of light-actuated cavitands. Therefore, attaching one of the bipyridine ligands of the $\left[\mathrm{Ru}(\mathrm{bpy})_{3}\right]^{2+}$ complex to a quinoxaline wall as an appropriate design that does not drastically alter the optoelectronic properties of the dye. Accordingly, dipyridophenazine (dppz) ligand was found to meet these criteria, while its chemical versatility, photophysics, and light-switching properties have been extensively investigated. ${ }^{[17-18]}$ Thus, we designed cavitand $\mathbf{1}$, a system where the donor ([Ru(bpy $\left.\left.)_{2}(\mathrm{dppz})\right]^{2+}\right)$ and the acceptor (Q) are positioned on the adjacent cavitand walls, yet within distance range that can ensure intramolecular PET (Fig. 1b). 
a)

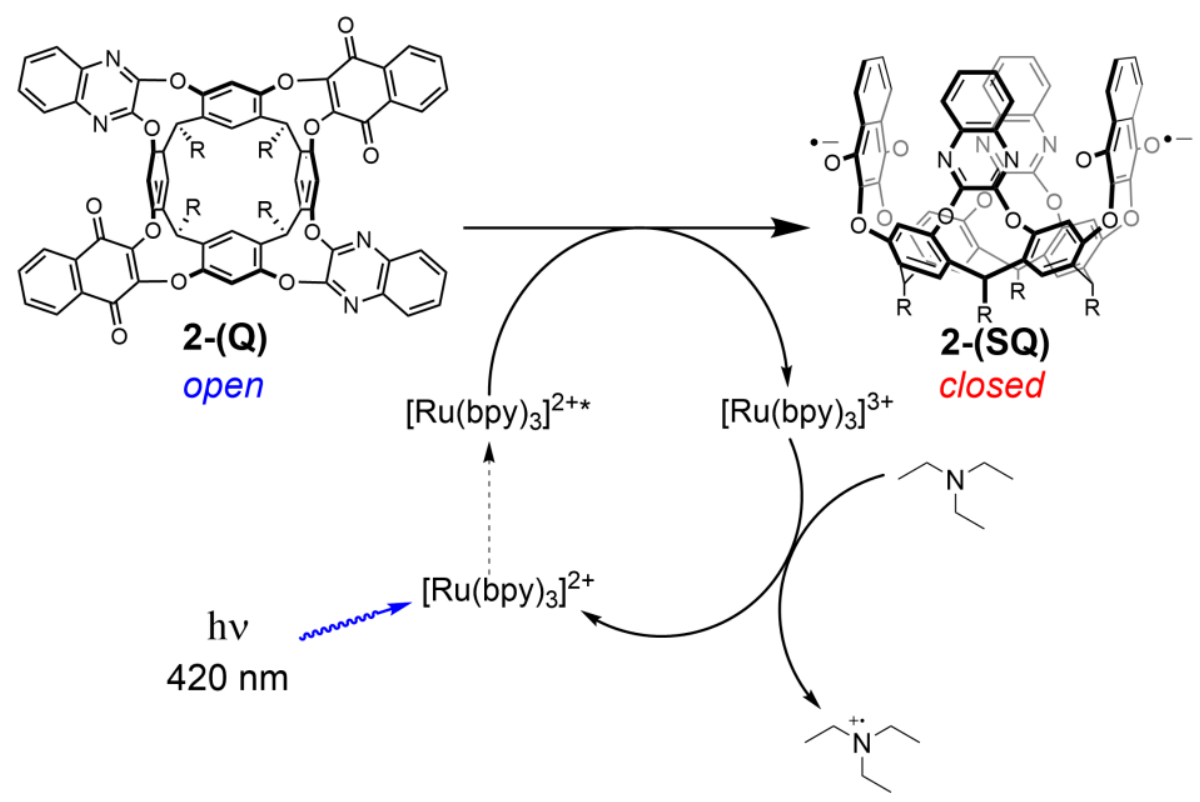

b)

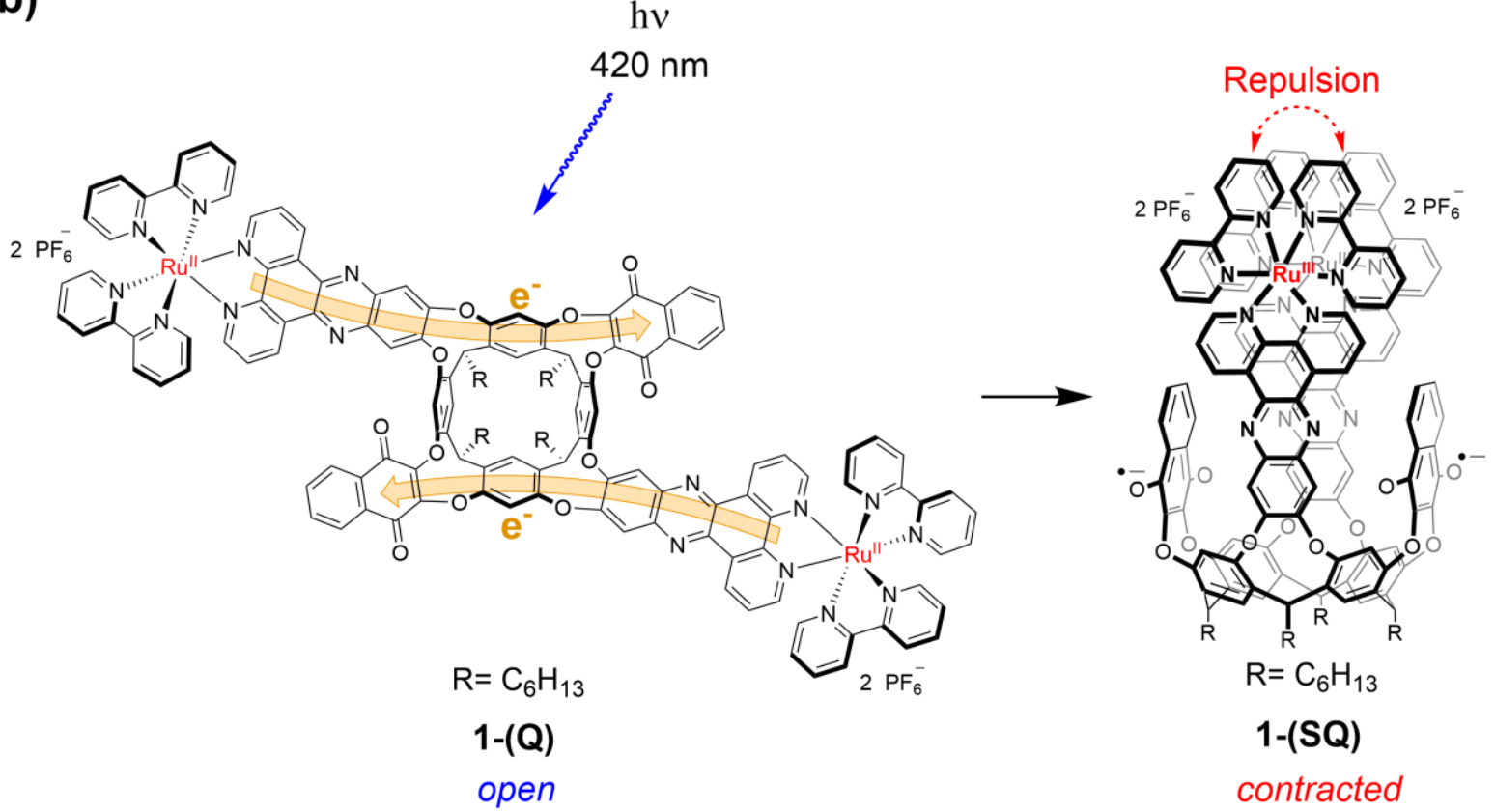

Fig. 1. a) Previously reported cavitand activated by intermolecular electron transfer. ${ }^{[13-14]}$ b) Cavitand $\mathbf{1}$ activated by intramolecular electron transfer; the full closed conformation in the $\mathbf{S Q}$ cannot be achieved because of strong steric and electrostatic repulsion between the two Ru walls.

\subsection{Synthesis}

Synthesis of cavitand 1 required the preparation of wall precursor $\mathbf{4}$, which was accessed from the dppz ligand precursor 7 (Scheme 1). The dppz ligands 7 was synthesized according to a 
modified procedure ${ }^{[19]}$ through a condensation of 3,4-difluoro-1,2-enzenediamine (5) and 1,10phenanthroline-5,6-dione (6) in 71\% yield. Complex 4 was then prepared by heating to reflux ligand 7 and $\left[\mathrm{Ru}(\mathrm{bpy})_{2} \mathrm{Cl}_{2}\right]^{2+}$ in EtOH for one day. The dppz ligands $\mathbf{1 6}$ was synthesized according to a similar procedure through a condensation of 3,6-Dimethoxybenzene-1,2-diamine (15) and 1,10-phenanthroline-5,6-dione (6) in $71 \%$ yield.

Furthermore, model complex $\mathbf{3}$ was also prepared by heating to reflux ligand $\mathbf{1 6}$ and $\left[\mathrm{Ru}(\mathrm{bpy})_{2} \mathrm{Cl}_{2}\right]^{2+}$ in EtOH for one day (Scheme S1). After flash column chromatography, the obtained dichloride salt was subjected to an anion exchange reaction via $\mathrm{KPF}_{6}$ to give the corresponding $\mathrm{PF}_{6}{ }^{-}$salt 3 in a quantitative yield.

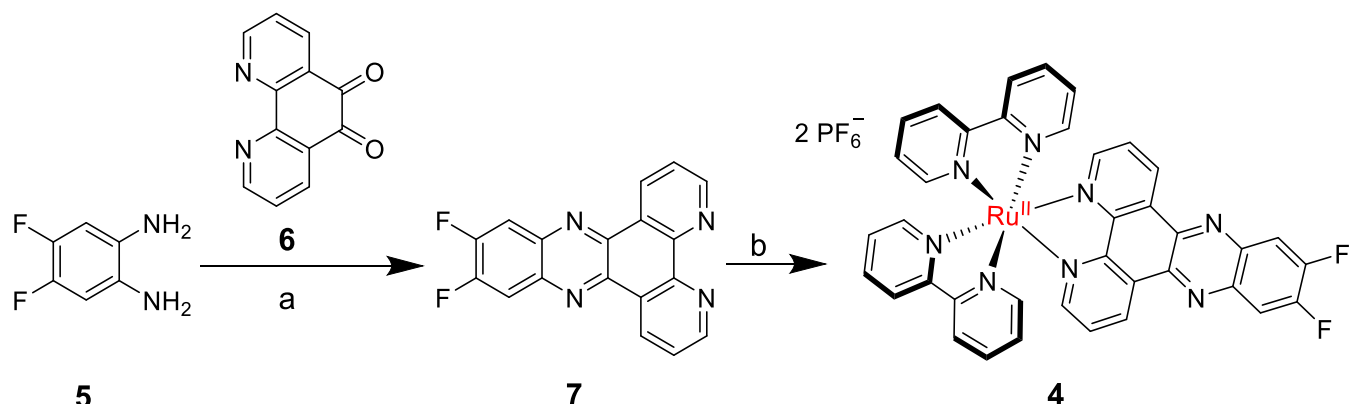

Scheme 1. Synthesis of $\left[\mathrm{Ru}(\mathrm{bpy})_{2}(\mathrm{dppz})\right]^{2+}$ precursor 4: (a) EtOH, reflux at $80{ }^{\circ} \mathrm{C}, 1 \mathrm{~h}, 71 \%$; (b) 1) $\left[\mathrm{Ru}(\text { bpy) })_{2} \mathrm{Cl}_{2}\right]^{2+}$, EtOH, reflux at $80{ }^{\circ} \mathrm{C}, 1 \mathrm{~d}$, 2) $\mathrm{KPF}_{6}, \mathrm{CH}_{3} \mathrm{CN}, 23{ }^{\circ} \mathrm{C}, 4 \mathrm{~h}, 99 \%$ (over two steps).

The resorcin[4]arene platform was assembled through condensation of resorcin[4]arene $\mathbf{8}$ with naphthoquinone derivative $\mathbf{9}$ giving cavitand $\mathbf{1 0}$ decorated with fours naphtoquinone walls. Treatment with catechol and $\mathrm{CsF}$ allowed a selective removal of two naphtoquinone walls in opposite sides affording thus the AC-diquinone terol 11. ${ }^{[6-7]}$ Finally, condensation of tetrol 11 with wall precursor $\mathbf{4}$ gave cavitand $\mathbf{1}$ in $37 \%$ yield (Scheme 2). 

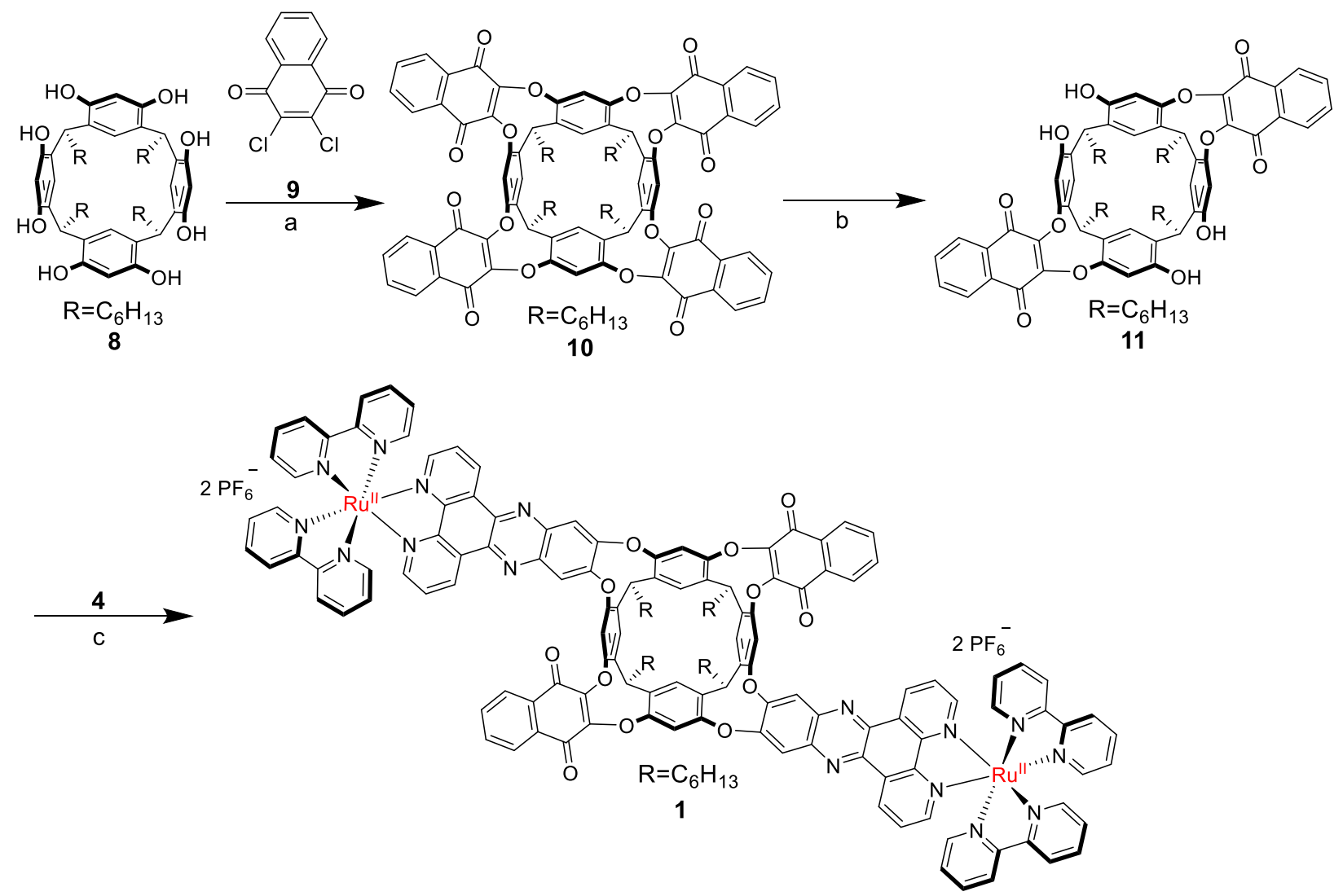

Scheme 2. Synthesis of cavitand 1; (a) $\mathrm{K}_{2} \mathrm{CO}_{3},\left(\mathrm{CH}_{3}\right)_{2} \mathrm{SO}, 50{ }^{\circ} \mathrm{C}, 16 \mathrm{~h}, 69 \%$; (b) catechol, CsF, DMF, $70{ }^{\circ} \mathrm{C}, 40 \mathrm{~min}, 35 \%$; (c) 1$) \mathrm{Cs}_{2} \mathrm{CO}_{3}$, DMF, $50{ }^{\circ} \mathrm{C}, 5 \mathrm{~h}$, 2) $\mathrm{KPF}_{6}, \mathrm{CH}_{3} \mathrm{CN}, 23{ }^{\circ} \mathrm{C}, 4 \mathrm{~h}, 37 \%$ (over two steps).

A model compound (12) resembling half of the resorcin[4]arene framework was designed to be used as a reference compound in the investigation of the photophysical properties of cavitand 1. This model 12 was synthesized in $97 \%$ yield by a nucleophilic aromatic substitution between 4 and phenol (Scheme 3).

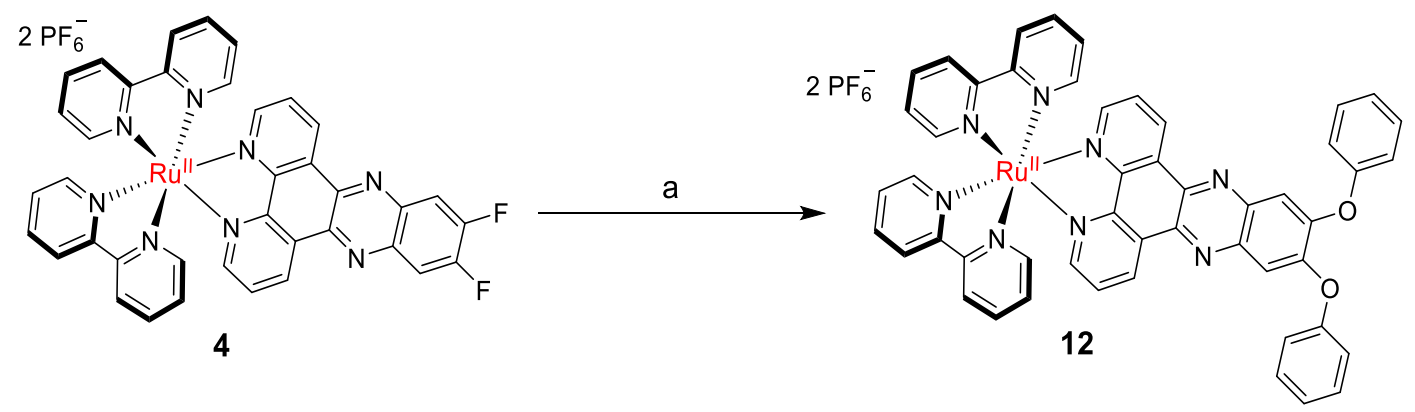

Scheme 3. Synthesis of model 12; (a) 1) Phenol, $\mathrm{Cs}_{2} \mathrm{CO}_{3}$, DMF, $\left.50{ }^{\circ} \mathrm{C}, 5 \mathrm{~h}, 2\right) \mathrm{KPF}_{6}, \mathrm{CH}_{3} \mathrm{CN}, 23$ ${ }^{\circ} \mathrm{C}, 4 \mathrm{~h}, 97 \%$ (over two steps).

\subsection{Geometry in the Oxidized (Quinone) State}


Previous examples of diquinone cavitands can adopt both the closed and open conformations depending on the solvent. ${ }^{[6-8]}$ We performed DFT B3LYP/6-31G(d) level of theory calculations to identify the structure of cavitand $\mathbf{1 - ( Q )}$ in both conformation. The geometry of $\mathbf{1 -}$ (Q) in the open conformation was in agreement with the crystal structures of those related diquinone cavitands (Fig. 2). ${ }^{[6-8]}$ On the contrary, the calculations indicate that electrostatic repulsion between the two charged $\mathrm{Ru}^{\mathrm{II}}$ centers and steric repulsion between the bulky bipyridine ligands hinder the full closure of the cavity. Nevertheless, a notorious contracted conformation was predicted. The largest movement upon contraction was observed on the quinone walls; the distance between them changed from $16.7 \AA$ in the open to $8 \AA$ in the contracted conformation. On the other hand, the walls with the $\mathrm{Ru}^{\mathrm{II}}$ complexes showed a limited contraction: the distance between quinoxaline motifs changed from $17.2 \AA$ to $15.8 \AA$, while the $\mathrm{Ru}^{\mathrm{II}}-\mathrm{Ru}{ }^{\mathrm{II}}$ distance changed only from $29.5 \AA$ to $26.0 \AA$.

a)
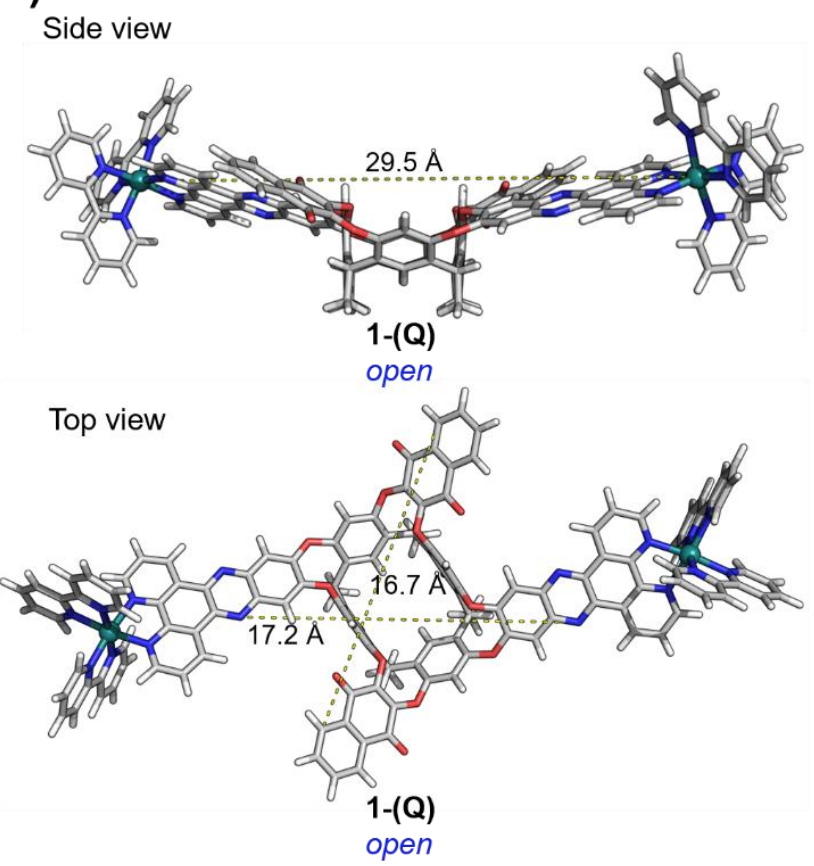

b)
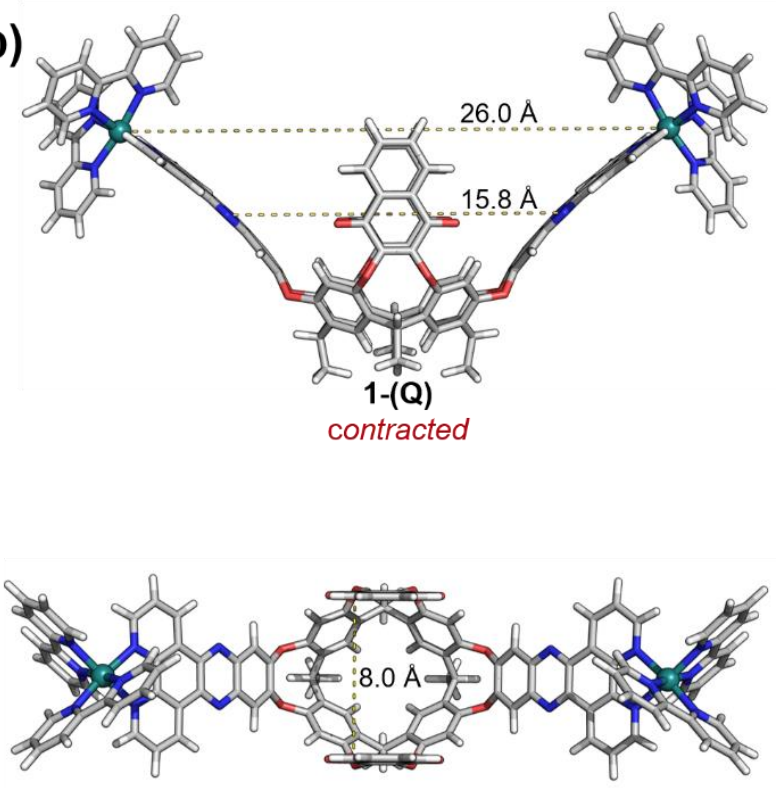

1-(Q)

contracted

Fig. 2. Optimized geometries (DFT B3LYP/6-31G(d)) of cavitand $\mathbf{1}$ in a) open and b) contracted conformations in the $\mathbf{Q}$ state.

As cavitands commonly adopt the open conformation in certain chlorinated solvents or those of small molecular size (such as $\mathrm{CD}_{2} \mathrm{Cl}_{2}, \mathrm{CD}_{3} \mathrm{CN}$, etc.), and the closed conformation in polar and aromatic solvents that accommodate the cavity as guest molecules (such as THF- $\mathrm{d}_{6}$, DMF- $\mathrm{d}_{7}$, 
$\mathrm{C}_{6} \mathrm{D}_{6}$, etc.), the actual conformation of cavitand $\mathbf{1 - Q}$ was determined experimentally by ${ }^{1} \mathrm{H}$ NMR spectroscopy in different solvents. For this purpose only polar solvents could be used due to solubility limitations. It was found that only the open conformation, identified by the methine protons located between $3.4-4.8$ ppm (*, Fig. 3), was preferred in all the solvents, including polar non-chlorinated solvents, such as DMF. In case of a vase conformation, the methine protons would have been between $5.5-6.0 \mathrm{ppm}$, which is not the case. ${ }^{[4,6-8]}$

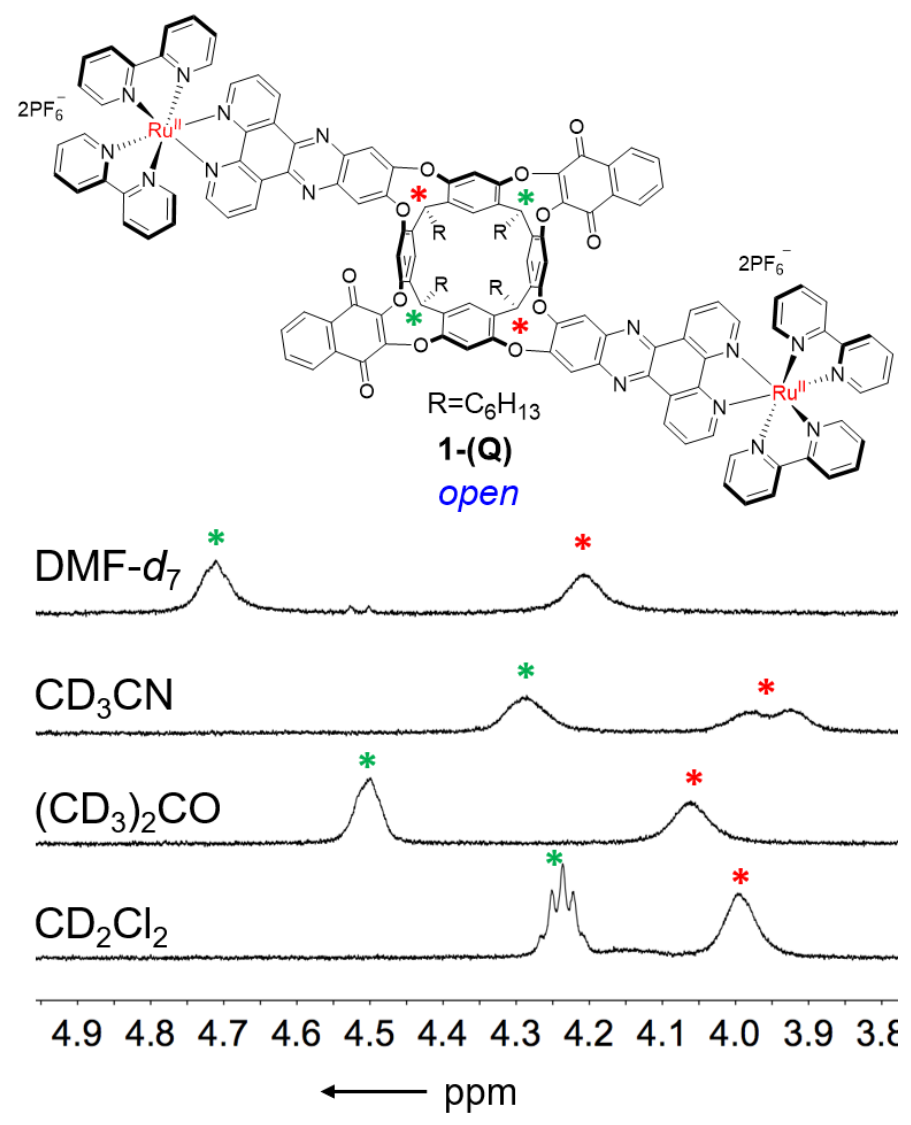

Fig. 3. Sections of the ${ }^{1} \mathrm{H}$ NMR spectra showing cavitand $\mathbf{1}\left(\mathrm{c}=10^{-2} \mathrm{M}, 300 \mathrm{MHz}, T=295 \mathrm{~K}\right)$ in the kite conformation in different solvents.

\subsection{Redox Properties}

The redox properties of $\mathbf{1}, \mathbf{4}$, and $\mathbf{1 2}$ were investigated in various solvents by cyclic voltammetry (CV), rotating disc voltammetry (RDV) or squarewave voltammetry (SWV) summarized in Table S1. Cyclic and rotating disc voltammograms of cavitand $\mathbf{1}$ in $\mathrm{CH}_{2} \mathrm{Cl}_{2}$ at ambient temperature show one reversible two-electron wave at $+0.98 \mathrm{~V}$ that corresponds to the oxidation of the $\mathrm{Ru}^{\mathrm{II}}$ to $\mathrm{Ru}{ }^{\mathrm{III}}$. Moreover, several reduction waves were observed that correspond 
to the stepwise reduction of the $\mathbf{Q}$ walls to the $\mathbf{S Q}$ radical anions $(-1.04 \mathrm{~V})$, the reduction of the dppz ligand $(-1.26 \mathrm{~V}$ and $-2.23 \mathrm{~V})$, the bipyridine ligands (bpy; $-1.35 \mathrm{~V}$ and $-1.75 \mathrm{~V}$ ), and the reduction of the $\mathbf{S Q}$ radical anions to the corresponding quinone dianion $\mathbf{Q}^{\mathbf{2}-}(-1.56 \mathrm{~V}$; Fig S1a and Table S1). After irradiation using white light (300 W Arc Xe lamp), the CV and RDV altered significantly, indicating a change in the electronic properties of the cavitand (Figure S1b).

Cyclic and rotating disc voltammograms of model cavitand 3 in $\mathrm{CH}_{3} \mathrm{CN}$ at ambient temperature give similar behavior than for 1: one reversible one-electron wave at $+0.96 \mathrm{~V}$ that corresponds to the oxidation of the $\mathrm{Ru}^{\mathrm{II}}$ to $\mathrm{Ru}^{\mathrm{III}}$ and several successive reduction waves corresponding to the stepwise reduction of the $\mathbf{Q}$ walls to the $\mathbf{S Q}$ radical anions, the reduction of the dppz ligand, and the bipyridine ligands (Fig S5a and Table S1).

Employing $\mathrm{CH}_{3} \mathrm{CN}$ or DMF as solvents instead of $\mathrm{CH}_{2} \mathrm{Cl}_{2}$ resulted in similar redox potential values, apart from the minor differences in the reduction potential of the bpy ligands and the appearance of the adsorption at the electrode (Table S1). This solvent-dependent CV and RDV can likely be attributed to highly charged intermediates whose stabilization and diffusion can be impacted by solvation.

Both model compounds $\mathbf{4}$ and $\mathbf{1 2}$ show similar redox behavior to cavitand $\mathbf{1}$, without featuring the corresponding $\mathbf{Q}$ reduction waves. Cyclic voltammograms in $\mathrm{CH}_{2} \mathrm{Cl}_{2}$ at ambient temperature show one reversible oxidation wave was observed at either $+0.99 \mathrm{~V}$ or $+1.00 \mathrm{~V}$ that can be attributed to the oxidation of the $\mathrm{Ru}^{\mathrm{II}}$ to $\mathrm{Ru} \mathrm{u}^{\mathrm{III}}$, which was accompanied by four reduction waves corresponding to the bpy and dppz ligands (Table S1 and Fig. S2 - S3). This indicates that the redox properties of the $\mathrm{Ru}$ complex do not change drastically after its incorporation into the resorcin[4]arene framework.

The feasibility of PET in cavitand $\mathbf{1}$ was assessed by estimating the driving force $(\Delta G)$ for photoreduction in $\mathrm{CH}_{2} \mathrm{Cl}_{2}$ based on the difference between the reduction potentials of the $\mathbf{Q}$ state $\left(E_{\text {red }}=-1.04 \mathrm{~V}\right.$; Table S1) and the oxidation potential of the $\mathrm{Ru}^{\mathrm{II}}$ in the excited state $\left(E^{*}{ }_{o x}\right)$ in accordance with the equation $(1)^{[20,21]}$

$$
\Delta G=\left(E_{o x}^{*}-E_{r e d}\right)[e V]
$$

The oxidation potential in the excited state $\left(E^{*}{ }_{o x}=-1.07 \mathrm{~V}\right)$ was estimated from the oxidation potential of the dye in the ground state $\left(E_{o x}=0.98 \mathrm{~V}\right.$; Table S1) and the zeroth vibrational transition between the excited and the ground states $\left(E_{0,0}=2.05 \mathrm{~V}\right)$, which was extracted from the corresponding emission spectrum of the dye $\left(\lambda_{\max }=606 \mathrm{~nm}\right.$; Fig. $\left.4 \mathrm{~b}\right)$ based on the equation $(2)^{[22,23]}$ 


$$
E_{o x}^{*}=E_{o x}-E_{0,0}
$$

The balance of the redox potentials resulted in the driving force of $-30 \mathrm{meV}$ (Table 1) for intramolecular PET in $\mathrm{CH}_{2} \mathrm{Cl}_{2}$ at ambient temperature $(T=298 \mathrm{~K})$ that corresponds to an exothermic process, which was therefore suitable for further investigation. Moreover, this driving force, although smaller, is of the same order of magnitude as the value of $-90 \mathrm{meV}$ that was obtained for the intermolecular photoreduction of a naphthoquinone gripper by $\left[\mathrm{Ru}(\mathrm{bpy})_{3}\right]^{2+}{ }^{[13]}$

\subsection{Photophysical Properties}

The photophysical properties of cavitand $\mathbf{1}$ and model $\mathbf{1 2}$ in the $\mathbf{Q}$ state were investigated by UV-Vis absorption and photoluminescence (PL) spectroscopy in $\mathrm{CH}_{2} \mathrm{Cl}_{2}$ at ambient temperature. Both molecules show the characteristic MLCT absorption bands at $390-550 \mathrm{~nm}$ and PL emission maxima between 600 and $610 \mathrm{~nm}$ (Fig. 4). The absorption of cavitand 1 is almost twice that in model 12, while the PL is lower, which accounts for the quenching induced by the quinones due to intramolecular electron transfer. The UV-Vis absorption spectra in DMF match to those in $\mathrm{CH}_{2} \mathrm{Cl}_{2}$ at ambient temperature, whereas the PL emission spectra show a bathochromic shift with a maximum emission at $655 \mathrm{~nm}$ (Fig. S9). Moreover, the PLintensity is 4-5 times lower than in $\mathrm{CH}_{2} \mathrm{Cl}_{2}$, suggesting potential PL quenching in presence of DMF.
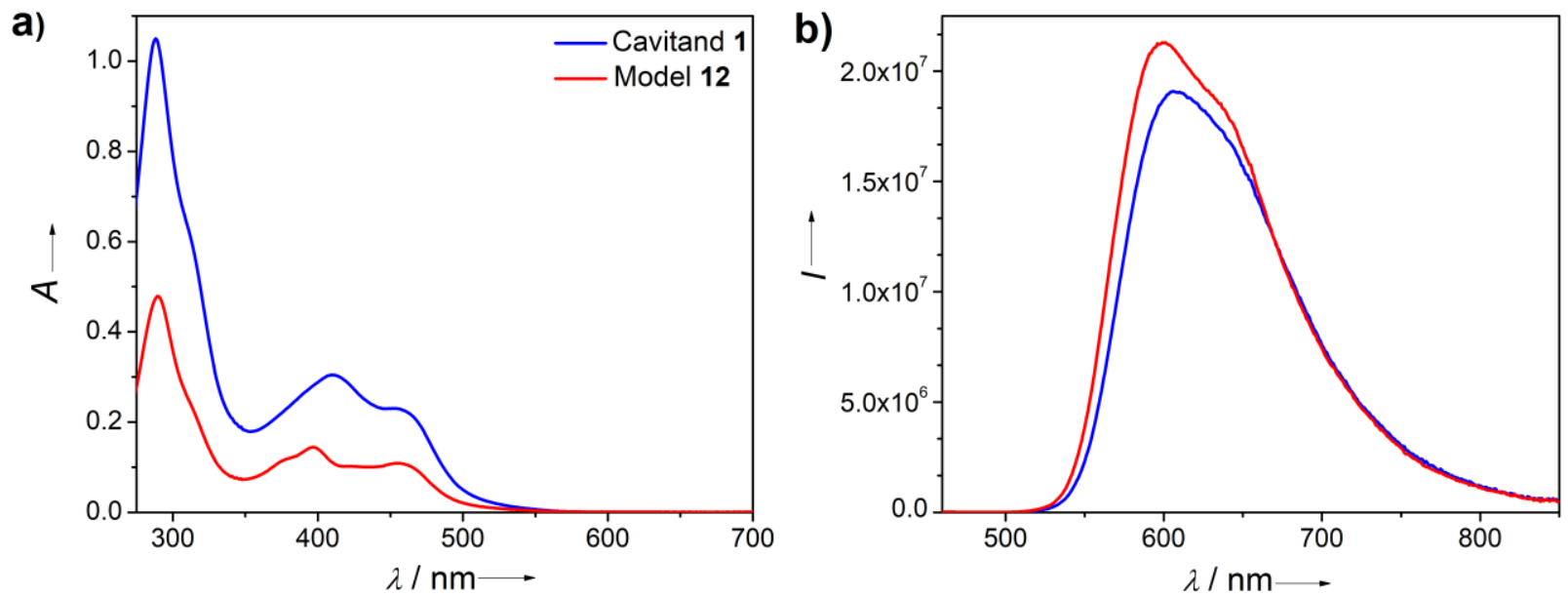

Fig. 4. a) UV-Vis absorption and b) emission spectra of cavitand 1 and model $12\left(10^{-6} \mathrm{M}\right.$ solutions in $\mathrm{CH}_{2} \mathrm{Cl}_{2}$ ) at $T=298 \mathrm{~K}$.

\subsection{Conformational Switching upon Reduction}


The conformational switching upon reduction of the $\mathbf{Q}$ cannot be monitored by NMR because of the generation of the SQ radical anion as paramagnetic species, whose unpaired electrons contribute to broadening and disappearance of proton resonances. Thus, UV-Vis spectroelectrochemistry was used as an alternative method. The $\mathbf{Q}$ states were first reduced electrochemically and chemically to ascertain the absorption signatures corresponding to the SQ in the contracted conformation. However, both the ruthenium complex and the SQ anion absorb in the same wavelength range $(400-500 \mathrm{~nm})$, which hampers the identification of the absorption trace originating from the SQ species. Therefore, the trace of the new species was isolated by plotting the differential absorption $(\Delta A)$ spectrum.

UV-Vis-NIR spectra in $\mathrm{CH}_{3} \mathrm{CN}$ upon the electrochemical first reduction of cavitand $\mathbf{1}$ revealed one new absorption band with a maximum at $512 \mathrm{~nm}$, which extends from $470 \mathrm{~nm}$ to the NIR region (Fig. 5a). In accordance with previously reported cavitands in the $\mathbf{S Q}$ state, ${ }^{[13,14]}$ this absorption band corresponds to the newly formed SQ radical species. Furthermore, the hyperchromic shift at $343 \mathrm{~nm}$ and the hypsochromic shifts of the bands < $330 \mathrm{~nm}$ and at $404 \mathrm{~nm}$ confirmed the contracted conformation (Fig. 5a).

The chemical reduction of cavitand 1 by two equivalents of cobaltocene $(\mathrm{Cp} 2 \mathrm{Co})$ in $\mathrm{DMF}$ at ambient temperature revealed similar absorption features to those observed by electrochemical reduction (Fig. 6a), namely a hypsochromic shift at $300-350 \mathrm{~nm}$, a hypochromic shift at $400 \mathrm{~nm}$, and a hyperchromic shift at $367 \mathrm{~nm}$ indicative of a contracted conformation, while the broad absorption between 440 - $700 \mathrm{~nm}$ confirms the formation of the SQ species. The correspondence of the differential absorption spectra $(\Delta A)$ obtained during both reduction approaches suggests that the same species was formed (Figs. 5b and 6b), whereas the small differences can be ascribed to using different solvents, the presence of conducting salt in the case of the spectroelectrochemistry study and different instrumental set up. 
a)

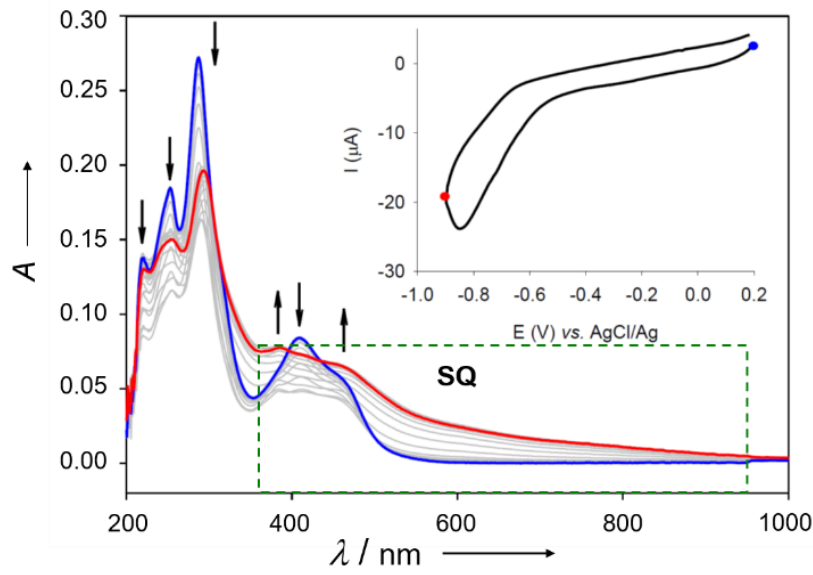

b)

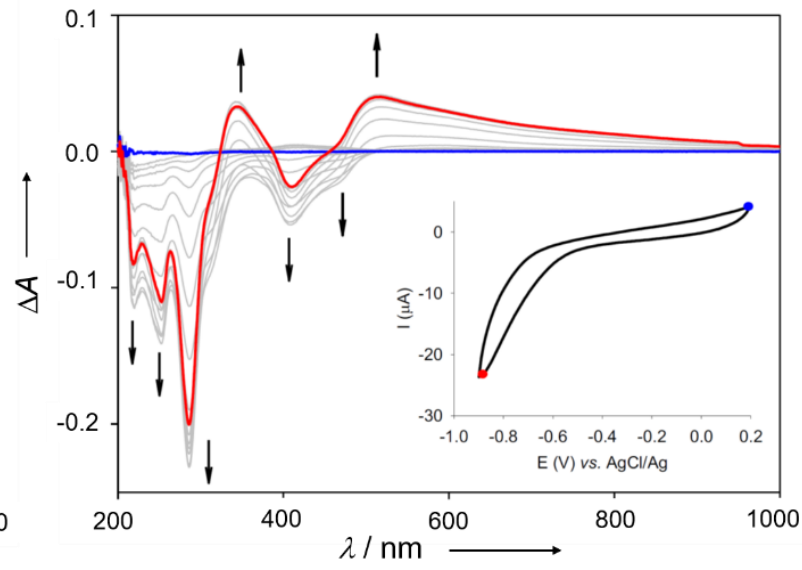

Fig. 5. (a) UV-Vis-NIR spectra upon electrochemical reduction of cavitand $\mathbf{1}$ in the potential region of the first reduction step in $0.1 \mathrm{M} n-\mathrm{Bu}_{4} \mathrm{NPF}_{6} / \mathrm{CH}_{3} \mathrm{CN}$ measured at $T=293 \mathrm{~K}$ with a scan rate of $0.01 \mathrm{Vs}^{-1}$ and the corresponding (b) differential UV-Vis-NIR spectra. Insets shows the cyclic voltammograms and the potentials (colored circles) where the UV-Vis-NIR spectra were taken.

a)

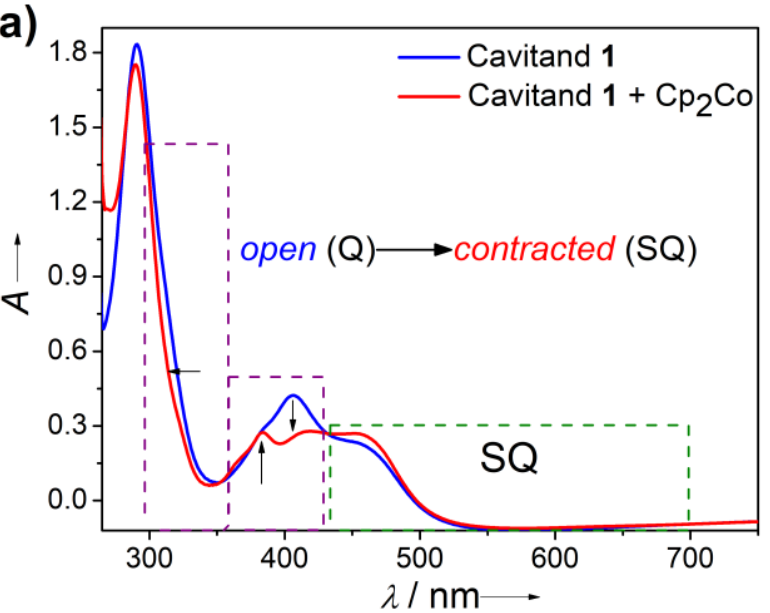

b) 0.05

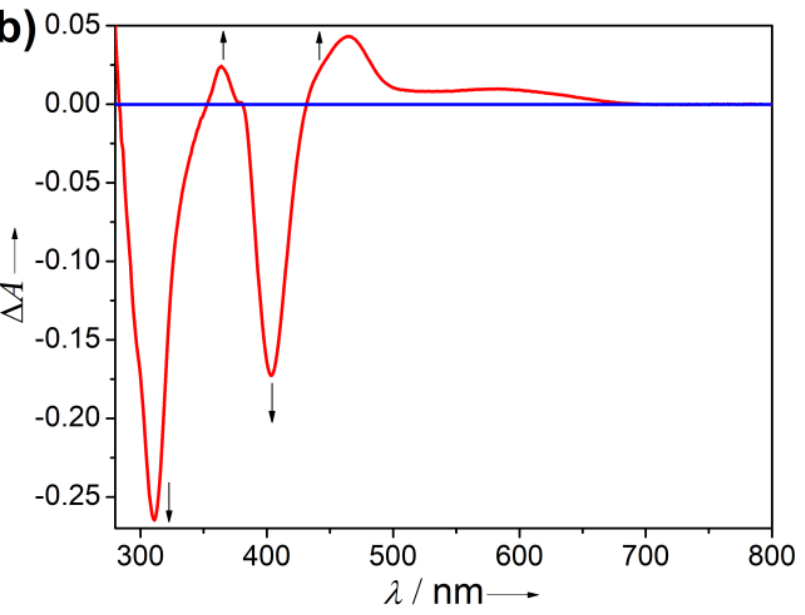

Fig. 6. (a) UV-Vis absorption of cavitand 1 before (blue) and after (red) addition of $\mathrm{Cp}_{2} \mathrm{Co}(1 \mu \mathrm{M}$ solutions in DMF; 2 equiv. of $\mathrm{Cp}_{2} \mathrm{Co}$ ) at $T=298 \mathrm{~K}$ with (b) the corresponding differential UV-Vis spectra. Green dashed box highlight the SQ formation while purple dashed boxes highlight the change in absorption due to conformational switching.

Having identified the conformational switch between the open and the contracted conformation of the cavitand upon electrochemical and chemical reduction of the $\mathbf{Q}$ to the $\mathbf{S Q}$ state, the light-activated conformational switching was investigated by UV-Vis spectroelectrochemistry and EPR spectroscopy. The solution of cavitand $\mathbf{1}$ in $\mathrm{CH}_{2} \mathrm{Cl}_{2}$ was irradiated at $420 \mathrm{~nm}$ at ambient temperature, however no strong evidence of the $\mathbf{S Q}$ formation was observed by either the EPR (Fig. 7a, green curve) or the UV-Vis spectroscopy (not shown). 
Assuming that the absence of SQ formation can be attributed to the lower efficiency of the intramolecular photoredox process compared to the electrochemical and chemical reduction, as well as the backward electron transfer, the photoexcitation of cavitand $\mathbf{1}$ was performed in presence of $\mathrm{Et}_{3} \mathrm{~N}$ as a sacrificial donor to regenerate the $\mathrm{Ru}^{\mathrm{II}}$ and accumulate the $\mathbf{S Q}$ species. The solution of cavitand 1 in $\mathrm{CH}_{2} \mathrm{Cl}_{2}$ was therefore irradiated and, immediately after, the solution was frozen to record the EPR spectrum, in order to lock the conformation in the solid state. EPR spectra of the frozen solutions of $\mathbf{1}$ in $\mathrm{CH}_{2} \mathrm{Cl}_{2}$ upon photoexcitation revealed spectral characteristics that correspond to a $\mathbf{S Q}$ radical anion with $g$ tensor principal values $g_{\mathrm{x}}=2.0022, g_{\mathrm{y}}=2.0056$, and $g_{\mathrm{z}}=$ 2.0059 (Fig. 7a, red curve). These parameters however suggest that the species generated upon excitation in the frozen solution can be assigned to a SQ radical anion that does not feature any zero field splitting (ZFS). This can occur if either mono-SQ species are formed in solution or the bis-SQ species in the open conformation do not engage in any dipole-dipole interactions, which is in line with the inability of the system to change the conformation upon excitation in the frozen solution.

In a separate experiment, the UV-Vis spectra of cavitand $\mathbf{1}$ was recorded before and after 15 min of irradiation at $420 \mathrm{~nm}$ in presence of $\mathrm{Et}_{3} \mathrm{~N}$ at ambient temperature (Fig. 7b). The subtle change in the absorption in the domain between $300-700 \mathrm{~nm}$ indicates the formation of the SQ accompanied by the switching from the open to the contracted conformation in agreement with the results obtained during chemical and electrochemical reduction. This observation confirms the light-actuation of cavitand $\mathbf{1}$ by means of intramolecular electron transfer in presence of sacrificial electron donor. 

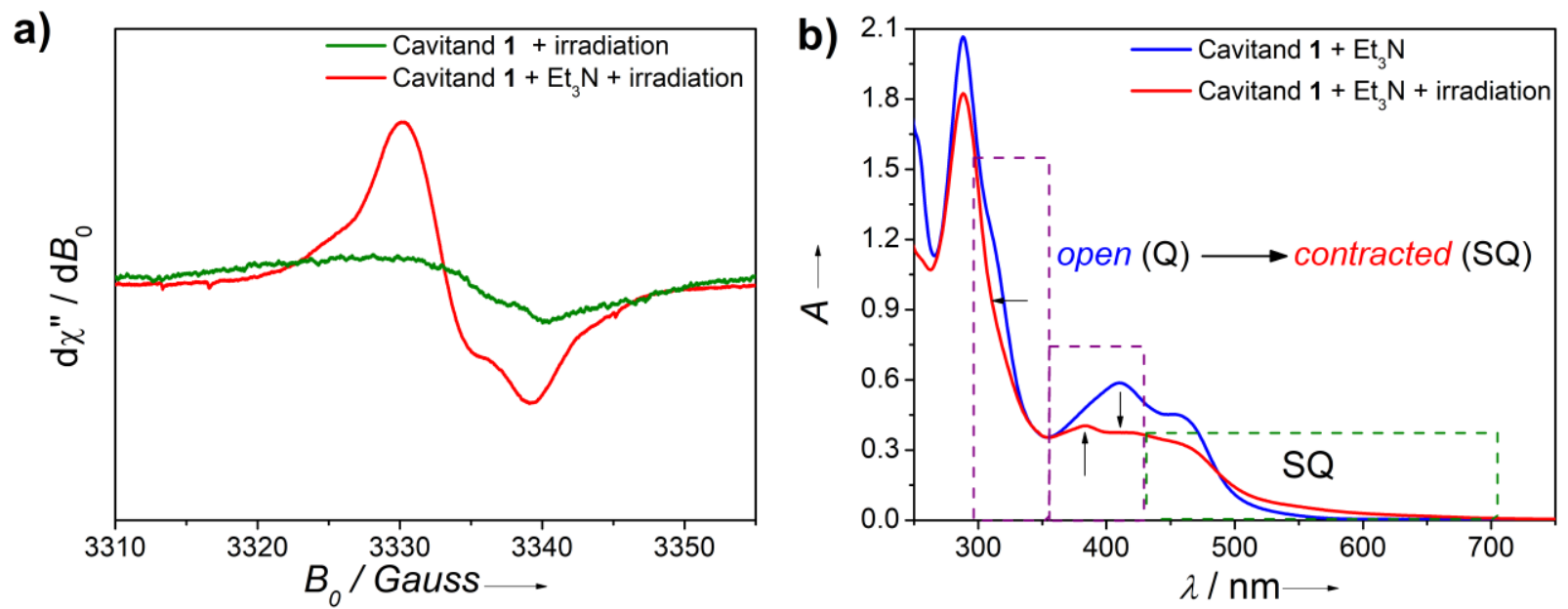

Fig. 7. Light-actuation of cavitand 1 in the solution of $\mathrm{CH}_{2} \mathrm{Cl}_{2}$ in presence of excess $\mathrm{Et}_{3} \mathrm{~N}$ (100 equiv.) as sacrificial electron donor. (a) EPR spectrum of $\mathbf{1}$ after irradiation with (red) and without (green) sacrificial donor at $T=120 \mathrm{~K}$. (b) UV-Vis absorption spectra after 15 min of irradiation at $420 \mathrm{~nm}\left(10^{-6} \mathrm{M}\right.$ solutions in $\mathrm{CH}_{2} \mathrm{Cl}_{2}$ with 100 equiv. of $\left.\mathrm{Et}_{3} \mathrm{~N}\right)$ at $T=298 \mathrm{~K}$. Green dashed box highlights the SQ formation (450-700 nm), while purple dashed boxes (300-350 nm) indicate the change in absorption due to conformational switching.

\subsection{Investigation of the Electron Transfer Process}

The underlying photoinduced process in absence of sacrificial donor was further investigated by transient absorption spectroscopy (TAS) and UV-Vis-NIR spectroelectrochemistry (SEC). The kinetic traces of the cavitand 1 were recorded between $320 \mathrm{~nm}$ and $750 \mathrm{~nm}$ in a time domain of $20 \mu \mathrm{s}$, which could be fitted globally to a tri-exponential fit. The global fit speciesassociated decay spectra (SADS) were obtained, with negative transient absorption signals ("negative decay") that reflect an absorbance of the corresponding species (Fig. 8a).

As the SADS analysis suggest, the initial spectrum at $t=0 \mathrm{~ns}$ (dashed orange line), calculated as the sum of all decay components, is formed by three transients in the electron transfer process. A decay with a time constant of approximately $25 \mathrm{~ns}$ (S1, red trace), which is mainly comprised of signals at $395 \mathrm{~nm}$ and $450 \mathrm{~nm}$ and a very weak band at $600 \mathrm{~nm}$, was tentatively assigned to the excited $\mathrm{Ru}$ II cavitand. The second component ( $\mathrm{S} 2$, green trace) decays with a time constant of $600 \mathrm{~ns}$, showing an intense emission band around $600 \mathrm{~nm}$ in combination with a weak signal around $520 \mathrm{~nm}$ and a bleach at $450 \mathrm{~nm}$. The spectrum of the $\mathrm{S} 2$ species was superimposable with the excited state spectrum of the reference model 12 (Fig. 8c). Furthermore, it featured a significant emission in combination with almost identical time constants of $600 \mathrm{~ns}$ (S2) and 550 ns to those of model 12, which leads to the assignments of S2 as the ${ }^{3}$ MLCT state of the 
chromophore which is not quenched by any electron transfer (Fig. 8b). The third SADS of cavitand 1 (S3, blue trace) decays with a time constant of $3.7 \mu$ s and shows a broad and intense absorption around $380 \mathrm{~nm}$ in combination with a weak signal at $500 \mathrm{~nm}$, which could be ascribed to a chargeseparated $\mathrm{Ru}^{\mathrm{III}} / \mathrm{SQ}$ state based on several observations: (1) this species is non-emissive, which implies that it does not correspond to $\mathrm{Ru}^{\mathrm{II}}$, (2) the spectral signatures of $\mathbf{S Q}$ and $\mathrm{Ru}^{\mathrm{III}}$ feature absorption bands around $400 \mathrm{~nm}$ as a major contribution, with the Ru-bleach around $450 \mathrm{~nm}$ that is expected to overlap with a positive signal of SQ, and (3) UV-Vis-NIR spectroelectrochemistry upon first electrochemical reduction of the cavitand $\mathbf{1}$ unveiled the same absorption bands in the $450-600 \mathrm{~nm}$ region originating from the SOMO-LUMO transitions characteristic for the SQ species (Fig. 4). ${ }^{[24,25]}$ TAS and SEC featured the same spectroscopic indicators, which evidenced that the photoreduction product corresponded to the target SQ species. If this charge-separated photoproduct is assigned to S3 and a non-quenched ${ }^{3}$ MLCT excited state to S2, it seems plausible to interpret the component $\mathrm{S} 1$ as the reaction of an initially excited $\mathrm{Ru}^{\mathrm{II}}$ complex to the chargeseparated state. This assignment is further supported by the fact that S1 shows a rather weak emission band around $600 \mathrm{~nm}$. Moreover, when assuming the spectral signature observed in S1 corresponds to $* \mathrm{Ru}^{\mathrm{II}} \rightarrow \mathrm{Ru}^{\mathrm{III}} / \mathbf{S Q}$, it should be comprised of the ${ }^{3}$ MLCT spectrum of the complex and the negative spectrum of $\mathrm{Ru}^{\mathrm{III}} / \mathbf{S Q}$ ( since it is forming and not decaying). If this assignment is correct, adding the spectral signature of decaying $\mathrm{Ru}^{\mathrm{III}} / \mathrm{SQ}$ (S3) to the component $\mathrm{S} 1$ would exclusively yield the spectrum of the excited Ru-complex. The comparison of this difference spectrum of S1/S3 and the assigned ${ }^{3}$ MLCT spectrum (S2) shown in Fig. 8d features remarkable similarities between the two spectral signatures, in accordance with the spectral assignments.

Alternative assignments of the S2 species were considered, despite it showing almost identical spectral signatures and lifetimes $(\sim 600 \mathrm{~nm})$ as the reference complex 12 that supports the assignment to the unquenched excited state of the ruthenium complex. This can refer to, for instance, an additional excited state decay pathway or another photoproduct that decays much faster and can therefore not be detected. Potential contaminations can however be discarded, as high resolution mass spectrometry (HRMS) and NMR measurements (Section S6 of the Supporting Information) of cavitand 1 show that the samples are highly pure and without detectable residues of $\mathbf{4}$ or any other Ru species. Photolysis of the cavitand can be excluded as well, as these types of resorcin[4]arene based cavitands are stable to photoexcitation. ${ }^{[13,14]}$ 


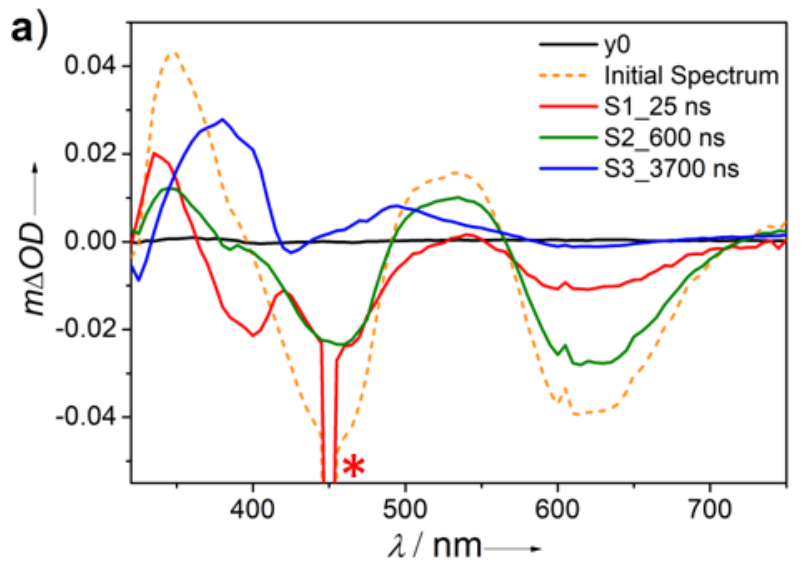

b)
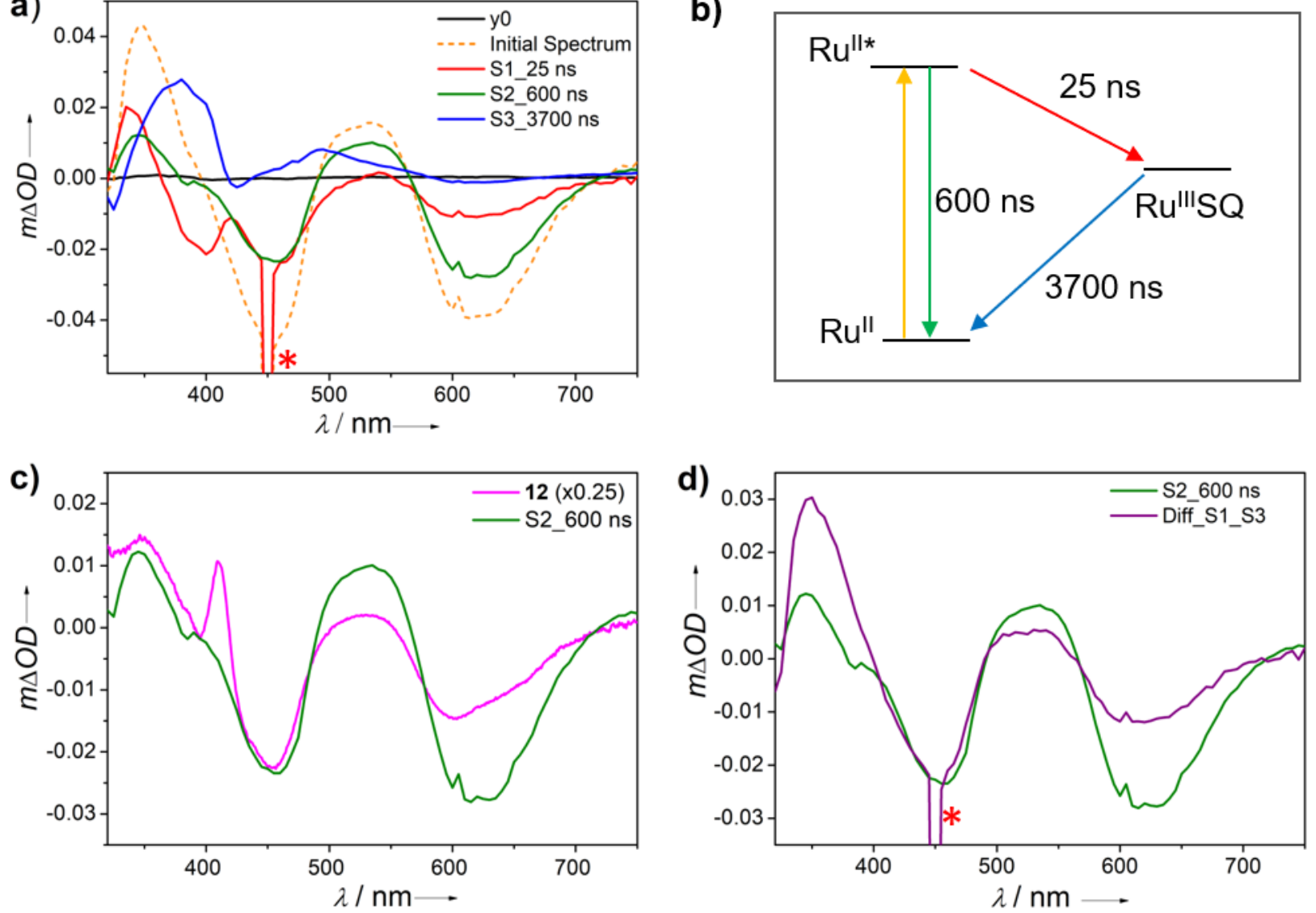

Fig. 8. (a) Species-associated decay spectra (SADS) obtained after excitation of cavitant 1 at $450 \mathrm{~nm}$ in degassed $\mathrm{CH}_{2} \mathrm{Cl}_{2}$. The decay spectra were obtained by fitting the kinetic traces in a $20 \mu$ s time domain between $320 \mathrm{~nm}$ and $750 \mathrm{~nm}$ globally to a tri-exponential decay. (b) Schematic representation of the relevant photoexcited and charge-separated states which can be formed in cavitand 1. (c) Comparison between SADS with $600 \mathrm{~ns}$ (green trace) and the transient absorption spectrum of the excited state of the reference complex 12 (pink trace). (d) Comparison between SADS with $600 \mathrm{~ns}$ (green trace) and a spectrum obtained by adding the SADS with $3700 \mathrm{~ns}$ (S3) to the $25 \mathrm{~ns}$ (S1) component (purple trace). The resulting spectrum corresponds well to the SADS of the species identified as S2, as shown in c). * Indicates stray light from laser excitation.

Based on the SADS analysis, the kinetics after excitation of cavitand $\mathbf{1}$ in $\mathrm{CH}_{2} \mathrm{Cl}_{2}$ is rather complex and comprised of three species (Fig. 8b). The rates for the charge separation $\left(K_{C S}\right)$ and charge recombination $\left(K_{C R}\right)$ are roughly estimated from the decay traces values (S1 and S3) and are reported in Table 1. Cavitand $\mathbf{1}$ has $K_{C S}$ and $K_{C R}$ values two orders of magnitude smaller than the diffusion-controlled intermolecular PET in previously reported cavitands, which is in accordance with the less efficient intramolecular PET observed.

Table 1. Driving force $(\Delta G)$, charge separation $\left(K_{C S}\right)$ and charge recombination $\left(K_{C R}\right)$ rates for previously reported intermolecular $\mathrm{PET}^{[13]}$ and intramolecular $\mathrm{PET}$ of cavitand $\mathbf{1}$ in $\mathrm{CH}_{2} \mathrm{Cl}_{2}$. 


\begin{tabular}{lcc}
\hline & $\begin{array}{c}\text { Intermolecular } \\
\text { PET }^{[13]}\end{array}$ & $\begin{array}{c}\text { Intramolecular } \\
\text { PET }\end{array}$ \\
\hline$\Delta \boldsymbol{G}(\mathrm{meV})$ & -90 & -30 \\
\hline $\boldsymbol{K}_{\boldsymbol{C S}}\left(\mathrm{M}^{-1} \mathrm{~s}^{-1}\right)$ & $2.3 \times 10^{9}$ & $4.0 \times 10^{7}$ \\
\hline $\boldsymbol{K}_{\boldsymbol{C R}}\left(\mathrm{M}^{-1} \mathrm{~s}^{-1}\right)$ & - & $2.7 \times 10^{5}$ \\
\hline
\end{tabular}

\section{Conclusions}

This work presents the development of the first light-actuated resorcin[4]arene cavitand (1) that does not require an external photoredox catalyst to operate. This cavitand consists of two quinone $(\mathbf{Q})$ walls, as electron acceptor units, and two $\mathrm{Ru}^{\mathrm{II}}$-based photoredox catalysts installed directly within the cavitand backbone for intramolecular photoinduced electron transfer. NMR studies reveal that an open conformation is preferred in the $\mathbf{Q}$ state, whereas DFT calculations in the $\mathbf{Q}$ state indicate that electrostatic and steric repulsion between the Ru complexes restrict a full closure of the cavity, suggesting however that significantly contracted conformation is feasible. The electrochemical and spectroscopic properties suggest that the electron transfer is favorable $(\Delta G=-30 \mathrm{meV})$. The reduced (semiquinone radical anion, SQ) state was thus successfully generated electrochemically, by cyclic voltammetry, chemically, by a reaction with cobaltocene, and photochemically, by intramolecular photoinduced electron transfer in presence of triethylamine as sacrificial electron donor. As a result, the changes in the UV-Vis absorption spectra upon SQ formation were observed, confirming the switching from the open to the contracted conformation that provide the final evidence for the light-induced actuation.

The photoinduced electron transfer without sacrificial donor was studied by transient absorption measurements and it was found that the charge-separated state is formed within $25 \mathrm{~ns}$ while the slower charge recombination takes $3.7 \mu \mathrm{s}$. Moreover, an intense signal corresponding to ${ }^{3}$ MLCT excited state of $\mathrm{Ru}^{\mathrm{II}}$ was identified, suggesting unquenched $\mathrm{Ru}^{\mathrm{II}}$, an additional unknown excited state decay pathway, or an unknown photoproduct that decays much faster and can therefore not be detected. Therefore, the use of a sacrificial electron donor to enhance the efficiency of the electron transfer was imperative. Further tailoring of this molecular prototype can lead to advanced light-activated molecular grippers that can function without sacrificial donor. 


\section{Experimental Section}

\subsection{Synthesis}

\subsubsection{Materials and Methods}

All glassware was oven-dried overnight prior to use and the reactions were performed under nitrogen atmosphere, unless otherwise noted. Octol $\mathbf{8}$ was synthesized according to a reported procedure. ${ }^{[6]}$ All other chemicals were purchased from commercial suppliers as reagent grade and used without further purification. Solvents for extraction or column chromatography were distilled from technical grade. Dry solvents (THF, DMF, $\mathrm{CH}_{3} \mathrm{CN}, \mathrm{CH}_{2} \mathrm{Cl}_{2}$ ) for reactions were purified by a solvent drying system from LC Technology Solutions Inc. SP-105 under nitrogen atmosphere ( $\mathrm{H}_{2} \mathrm{O}$ content $<10 \mathrm{ppm}$ as determined by Karl-Fischer titration). $\mathrm{HPLC}$ grade $\mathrm{CH}_{3} \mathrm{CN}, \mathrm{CH}_{2} \mathrm{Cl}_{2}$, and $\mathrm{H}_{2} \mathrm{O}$ were used in the anion exchange protocol. All other solvents were purchased in p.a. quality. Flash column chromatography (FC) was performed using $\mathrm{SiO}_{2}(60 \AA$, 230-400 mesh, particle size $0.040-0.063 \mathrm{~mm}$, Fluka) at $25{ }^{\circ} \mathrm{C}$ with a head pressure of $0.2-0.5$ bar. Thin layer chromatography (TLC) was performed using aluminum sheets coated with silica gel 60 F254 (Merck, Macherey-Nagel). Visualization was achieved using UV light (254 or $366 \mathrm{~nm}) .{ }^{1} \mathrm{H},{ }^{13} \mathrm{C}$ and ${ }^{19} \mathrm{~F}$ nuclear magnetic resonance (NMR) spectra were recorded on Bruker DRX 400 or Bruker AV 400 at $400 \mathrm{MHz}\left({ }^{1} \mathrm{H}\right), 101 \mathrm{MHz}\left({ }^{13} \mathrm{C}\right), 376 \mathrm{MHz}\left({ }^{19} \mathrm{~F}\right)$, or Bruker AV 500 spectrometers at $500 \mathrm{MHz}\left({ }^{1} \mathrm{H}\right), 125 \mathrm{MHz}\left({ }^{13} \mathrm{C}\right)$, and $471 \mathrm{MHz}\left({ }^{19} \mathrm{~F}\right)$. The temperature of measurement is indicated in the procedures and the corresponding figure captions. Chemical shifts $\delta$ are reported in ppm using the residual non-deuterated solvent signals as an internal reference $\left(\mathrm{CDCl}_{3}: \delta_{\mathrm{H}}=7.26 \mathrm{ppm}\right.$, $\delta_{\mathrm{C}}=77.16 \mathrm{ppm} ; \mathrm{CD}_{2} \mathrm{Cl}_{2}: \delta_{\mathrm{H}}=5.32 \mathrm{ppm}, \delta_{\mathrm{C}}=53.84 \mathrm{ppm} ;\left(\mathrm{CD}_{3}\right)_{2} \mathrm{CO}: \delta_{\mathrm{H}}=2.05 \mathrm{ppm}, \delta_{\mathrm{C}}=$ $29.84 \mathrm{ppm}) ; \mathrm{CD}_{3} \mathrm{CN}: \delta_{\mathrm{H}}=1.94 \mathrm{ppm}, \delta_{\mathrm{C}}=1.32 \mathrm{ppm}$; THF- $d_{8}: \delta_{\mathrm{H}}=3.58 \mathrm{ppm}, \delta_{\mathrm{C}}=67.21 \mathrm{ppm}$; DMF- $d_{7}: \delta_{\mathrm{H}}=2.92 \mathrm{ppm}, \delta_{\mathrm{C}}=34.89 \mathrm{ppm}$. For ${ }^{1} \mathrm{H}$ NMR spectra, coupling constants $J$ are given in $\mathrm{Hz}$ and the resonance multiplicity is described as s (singlet), $\mathrm{d}$ (doublet), $\mathrm{t}$ (triplet), $\mathrm{m}$ (multiplet), and br. (broad). Assignments are based on COSY, HSQC and HMBC experiments. Highresolution mass spectrometry (HR-MS) was performed by the MS-service of the Laboratory of Organic Chemistry at ETH Zurich on a Varian IonSpec FT-ICR spectrometer (MALDI). The 
matrix was 2-[(2E)-3-(4-tert-butylphenyl)-2-methylprop-2-enylidene]malononitrile (DCTB) or 3hydroxypyridine-2-carboxylic acid (3-HPA). The most important peaks and clusters are reported in $m / z$ units with $M^{+}$as the molecular ion and with the corresponding intensities in $\%$.

\subsubsection{Synthetic Procedures}

\subsubsection{Ruthenium-labeled cavitand 1}

A solution of diquinone tetrol $11(100 \mathrm{mg}, 0.088 \mathrm{mmol})$ and wall precursor 4 (188 $\mathrm{mg}$, $0.184 \mathrm{mmol})$ in dry DMF $(25 \mathrm{~mL})$ was treated with $\mathrm{Cs}_{2} \mathrm{CO}_{3}(172 \mathrm{mg}, 0.53 \mathrm{mmol})$, heated to $50{ }^{\circ} \mathrm{C}$ for $5 \mathrm{~h}$ under $\mathrm{N}_{2}$ atmosphere, cooled to $23{ }^{\circ} \mathrm{C}$, and evaporated. $\mathrm{FC}\left(\mathrm{SiO}_{2}\right.$; acetone/sat. aq. $\mathrm{KNO}_{3}$ 9:1) gave 1 as a dichloride salt. The pure solid was re-dissolved in $\mathrm{CH}_{3} \mathrm{CN}(10 \mathrm{~mL})$, treated with $\mathrm{KPF}_{6}(353 \mathrm{mg}, 1.92 \mathrm{mmol})$, stirred at $23{ }^{\circ} \mathrm{C}$ for $4 \mathrm{~h}$ under nitrogen atmosphere in the dark, and evaporated. The solid was re-dissolved in $\mathrm{CH}_{2} \mathrm{Cl}_{2}(20 \mathrm{~mL})$ and washed with $\mathrm{H}_{2} \mathrm{O}(3 \mathrm{x} 40 \mathrm{~mL})$. The organic layer was concentrated and the resulting solid was dried to afford $\mathbf{1}(100 \mathrm{mg}, 37 \%)$ as red powder. $R_{\mathrm{f}}=0.24\left(\mathrm{SiO}_{2}\right.$; acetone/sat. aq. $\left.\mathrm{KNO}_{3} 8: 2\right) ;{ }^{1} \mathrm{H} \mathrm{NMR}\left(400 \mathrm{MHz}, \mathrm{CD}_{2} \mathrm{Cl}_{2}, 296 \mathrm{~K}\right)$ : $\delta=0.71-0.85$ (m, 12 H; R), 1.09-1.31 (m, 32 H; R), 1.88-2.10 (m, 8 H; R), 4.03 (m, 2 H), 4.27 (m, 2 H), 6.34 (br s, 2 H), 7.13 (br s, 2 H), 7.29-7.42 (m, 4 H), 7.46-7.69 (m, 12 H), 7.72-8.08 (m, $18 \mathrm{H}), 8.09-8.36(\mathrm{~m}, 14 \mathrm{H}), 8.44-8.70(\mathrm{~m}, 8 \mathrm{H}), 8.94-9.64(\mathrm{~m}, 2 \mathrm{H}), 9.84$ ppm (br s, $2 \mathrm{H}) ;{ }^{13} \mathrm{C}$ NMR (101 MHz, $\left.\mathrm{CD}_{2} \mathrm{Cl}_{2}, 2{ }^{\circ} \mathrm{C}\right): \delta=14.07,14.08,22.85,22.91,27.23,27.42,29.27,29.45,31.68$, 31.82, 31.93, 31.99, 35.73, 36.94, 109.92, 110.26, 115.10, 115.61, 118.41, 118.74, 121.10, 121.68, $124.60,124.74,126.43,128.53,128.67,130.36,131.15,134.24,135.35,138.56,138.74,140.53$, 141.69, 148.02, 149.98, 150.04, 152.12, 153.49, 155.05, 157.21, 157.31, 157.33, 178.94 (C=O), $180.88 \mathrm{ppm}(\mathrm{C}=\mathrm{O}) ;{ }^{19} \mathrm{~F}$ NMR $\left(376 \mathrm{MHz}, \mathrm{CD}_{2} \mathrm{Cl}_{2}, 23{ }^{\circ} \mathrm{C}\right) \delta=-72.54\left(\mathrm{~d},{ }^{1} J(\mathrm{~F}, \mathrm{P})=712.4 \mathrm{~Hz} ; 4\right.$ PF6) ppm; HR-MALDI-MS: m/z (\%): 2957.6386 (15), 2956.6365 (29), 2955.6359 (46), 2954.6345

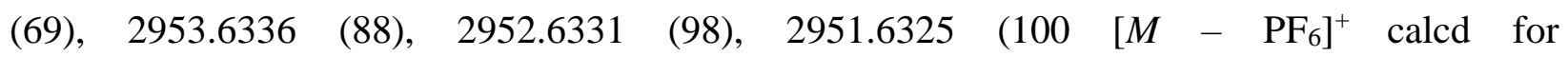
$\mathrm{C}_{148} \mathrm{H}_{120} \mathrm{~F}_{18} \mathrm{~N}_{16} \mathrm{O}_{12} \mathrm{P}_{3}{ }^{102} \mathrm{Ru}_{2}{ }^{+}$: 2951.6333), 2950.6322 (87), 2949.6319 (69), 2948.6325 (52), 2947.6327 (36), 2946.6332 (25), 2945.6331 (17).

\subsubsection{2. ( \pm$)-\left[(\text { bpy })_{2}(11,12\right.$-difluorodipyrido[3,2-a:2',3'-} c]phenazine)ruthenium(II)]bis(hexafluorophosphate)(4) 
A solution of $7(250 \mathrm{mg}, 0.79 \mathrm{mmol})$ in $\mathrm{EtOH}(50 \mathrm{~mL})$ was treated with $\left[\mathrm{Ru}(\mathrm{bpy})_{2} \mathrm{Cl}_{2}\right] \times \mathrm{H}_{2} \mathrm{O}$ (460 mg, $0.95 \mathrm{mmol}$ ), heated to reflux for $1 \mathrm{~d}$, cooled to $23{ }^{\circ} \mathrm{C}$, and evaporated. $\mathrm{FC}\left(\mathrm{SiO}_{2}\right.$; acetone/sat. aq. $\mathrm{KNO}_{3}$ 9:1) gave $\mathbf{4}$ as a dichloride salt. The solid was re-dissolved in $\mathrm{CH}_{3} \mathrm{CN}$ (10 $\mathrm{mL})$, treated with $\mathrm{KPF}_{6}(1.45 \mathrm{~g}, 7.9 \mathrm{mmol})$, stirred at $23{ }^{\circ} \mathrm{C}$ for $4 \mathrm{~h}$ under nitrogen atmosphere in the dark, and evaporated. The pure solid was re-dissolved in $\mathrm{CH}_{2} \mathrm{Cl}_{2}(50 \mathrm{~mL})$, then washed with $\mathrm{H}_{2} \mathrm{O}(3 \times 75 \mathrm{~mL})$, and evaporated. Drying the solid in high vacuum gave $4(800 \mathrm{mg}, 0.78 \mathrm{mmol}$, 99\%) as a red powder. $R_{\mathrm{f}}=0.26\left(\mathrm{SiO}_{2}\right.$; acetone/sat. aq. $\left.\mathrm{KNO}_{3} 9: 1\right) ;{ }^{1} \mathrm{H} \mathrm{NMR}\left(400 \mathrm{MHz}, \mathrm{CD}_{2} \mathrm{Cl}_{2}\right.$, $\left.23{ }^{\circ} \mathrm{C}\right): \delta=7.35$ (ddd, $\left.J=7.2,5.7,1.4 \mathrm{~Hz}, 2 \mathrm{H} ; 2 \mathrm{H}-\mathrm{C}\left(8^{\prime}\right)\right), 7.54(\mathrm{ddd}, J=7.3,5.6,1.3 \mathrm{~Hz}, 2 \mathrm{H} ; 2$ H-C(3’)), 7.73 (dd, $J=5.8,1.4, \mathrm{~Hz}, 2 \mathrm{H} ; 2$ H-C(7')), 7.85 (dd, $J=5.8,1.4, \mathrm{~Hz}, 2 \mathrm{H} ; 2$ H-C(2')), 7.97 (dd, $J=8.3,5.3 \mathrm{~Hz}, 2 \mathrm{H} ; \mathrm{H} 2, \mathrm{H}-\mathrm{C}(2,7)), 8.03$ (td, $\left.J=7.9,1.5 \mathrm{~Hz}, 2 \mathrm{H} ; 2 \mathrm{H}-\mathrm{C}\left(9^{\prime}\right)\right), 8.13$ (td, $\left.J=7.9,1.5 \mathrm{~Hz}, 2 \mathrm{H} ; 2 \mathrm{H}-\mathrm{C}\left(4^{\prime}\right)\right), 8.16(\mathrm{dd}, J=5.4,1.4 \mathrm{~Hz}, 2 \mathrm{H} ; \mathrm{H}-\mathrm{C}(3,6)), 8.24\left(\mathrm{t},{ }^{3} J(\mathrm{H}, \mathrm{F})={ }^{4} J(\mathrm{H}, \mathrm{F})\right.$ $=9.2 \mathrm{~Hz}, 2 \mathrm{H}, \mathrm{H}-\mathrm{C}(10,13)), 8.46$ and $8.49\left(2 \mathrm{dt}, J=8.3,1.0 \mathrm{~Hz}, 4 \mathrm{H} ; 2 \mathrm{H}-\mathrm{C}\left(5^{\prime}, 10^{\prime}\right)\right), 9.72 \mathrm{ppm}$ $(\mathrm{dd}, J=8.2,1.4 \mathrm{~Hz}, 2 \mathrm{H} ; \mathrm{H}-\mathrm{C}(1,8)) ;{ }^{13} \mathrm{C} \mathrm{NMR}\left(101 \mathrm{MHz}, \mathrm{CD}_{2} \mathrm{Cl}_{2}, 23{ }^{\circ} \mathrm{C}\right): \delta=115.57\left(\mathrm{dd},{ }^{2} J(\mathrm{C}, \mathrm{F})\right.$ $\left.=12.1 \mathrm{~Hz},{ }^{3} \mathrm{~J}(\mathrm{C}, \mathrm{F})=6.7 \mathrm{~Hz}, \mathrm{C}(10,13)\right), 124.80$ and $124.85\left(2 \mathrm{C}\left(5^{\prime}, 10^{\prime}\right)\right), 128.51(\mathrm{C}(2,7)), 128.74$ and $128.77\left(2 \mathrm{C}\left(3^{\prime}, 8^{\prime}\right)\right), 131.14(\mathrm{C}(8 \mathrm{a}, 14 \mathrm{~b})), 134.82(\mathrm{C}(1,8)), 138.80$ and $138.89\left(2 \mathrm{C}\left(4^{\prime}, 9^{\prime}\right)\right)$, $140.19(\mathrm{C}(8 \mathrm{~b}, 14 \mathrm{a})), 141.46\left(\mathrm{t},{ }^{3} J(\mathrm{C}, \mathrm{F})={ }^{4} J(\mathrm{C}, \mathrm{F})=5.6 \mathrm{~Hz}, \mathrm{C}(9 \mathrm{a}, 13 \mathrm{a})\right), 150.53(\mathrm{C}(4 \mathrm{a}, 4 \mathrm{~b})), 152.17$ and $152.23\left(2 \mathrm{C}\left(2^{\prime}, 7^{\prime}\right)\right), 154.08(\mathrm{C}(3,6)), 154.95\left(\mathrm{dd},{ }^{1} J(\mathrm{C}, \mathrm{F})=264.8 \mathrm{~Hz},{ }^{2} J(\mathrm{C}, \mathrm{F})=19.0 \mathrm{~Hz}\right.$, $\mathrm{C}(11,12)), 157.30$ and $157.45 \mathrm{ppm}\left(2 \mathrm{C}\left(5 \mathrm{a}^{\prime}, 10 \mathrm{a}^{\prime}\right)\right) ;{ }^{19} \mathrm{~F}$ NMR $\left(376 \mathrm{MHz}, \mathrm{CD}_{2} \mathrm{Cl}_{2}, 23{ }^{\circ} \mathrm{C}\right)$ : $\left.\delta=-72.76\left(\mathrm{~d},{ }^{1} J(\mathrm{~F}, \mathrm{P})=710.2 \mathrm{~Hz} ; 2 \mathrm{PF}_{6}\right)\right),-124.69 \mathrm{ppm}$; HR-MALDI-MS: $m / z(\%): 881.0837(5)$, 880.0803 (23), 879.0888 (7), 879.0765 (58), 879.0632 (5), 878.0793 (42), 877.0754 (100 [M $\left.\mathrm{PF}_{6}\right]^{+}$calcd for $\mathrm{C}_{38} \mathrm{H}_{24} \mathrm{~F}_{8} \mathrm{~N}_{8} \mathrm{P}^{102} \mathrm{Ru}^{+}$: 877.0782), 877.0622 (8), 876.0902 (6), 876.0772 (65), 871.0790 (17), 872,.0829 (6), 873.0762 (7), 874.0774 (39), 875.0748 (35).

\subsubsection{11,12-Difluorodipyrido[3,2-a:2',3'-c]phenazine (7)}

A solution of 5 (300 mg, $2.1 \mathrm{mmol})$ and $6(439 \mathrm{mg}, 2.1 \mathrm{mmol})$ in EtOH $(20 \mathrm{~mL})$ was heated to reflux for $1 \mathrm{~h}$ and cooled to $23{ }^{\circ} \mathrm{C}$. The precipitate was filtered off, washed with cold EtOH ( 25 $\mathrm{mL}$ ), and dried under vacuum to afford $7(470 \mathrm{mg}, 71 \%)$ as a gray solid. ${ }^{1} \mathrm{H}$ NMR (400 MHz, $\left.\mathrm{CDCl}_{3}, 23{ }^{\circ} \mathrm{C}\right): \delta=7.76(\mathrm{dd}, J=8.1,4.4 \mathrm{~Hz}, 2 \mathrm{H} ; \mathrm{H}-\mathrm{C}(2,7)), 8.0\left(\mathrm{t},{ }^{3} J(\mathrm{H}, \mathrm{F})={ }^{4} J(\mathrm{H}, \mathrm{F})=9.3 \mathrm{~Hz}, 2\right.$ H, H-C(10,13)), 9.25 (dd, $J=4.4,1.8 \mathrm{~Hz}, 2 \mathrm{H} ; \mathrm{H}-\mathrm{C}(3,6)), 9.47$ ppm (dd, $J=8.1,1.8 \mathrm{~Hz}, 2 \mathrm{H} ; \mathrm{H}-$ $\mathrm{C}(1,8)) ;{ }^{13} \mathrm{C}$ NMR $\left(101 \mathrm{MHz}, \mathrm{CDCl}_{3}, 23{ }^{\circ} \mathrm{C}\right): \delta=114.66\left(\mathrm{dd} ;{ }^{2} J(\mathrm{C}, \mathrm{F})=12.9 \mathrm{~Hz},{ }^{3} J(\mathrm{C}, \mathrm{F})=6.2\right.$ $\mathrm{Hz} ; \mathrm{C}(10,13)), 124.29(\mathrm{C}(2,7)), 127.04(\mathrm{C}(8 \mathrm{a}, 14 \mathrm{~b})), 133.72(\mathrm{C}(1,8)), 139.88\left(\mathrm{t},{ }^{3} J(\mathrm{C}, \mathrm{F})={ }^{4} J(\mathrm{C}, \mathrm{F})\right.$ 
$=5.9 \mathrm{~Hz} ; \mathrm{C}(9 \mathrm{a}, 13 \mathrm{a})), 141.10(\mathrm{C}(8 \mathrm{~b}, 14 \mathrm{a})), 148.34(\mathrm{C}(4 \mathrm{a}, 4 \mathrm{~b})), 152.93(\mathrm{C}(3,6)), 153.07 \mathrm{ppm}(\mathrm{dd}$, $\left.{ }^{1} J(\mathrm{C}, \mathrm{F})=261.01 \mathrm{~Hz},{ }^{2} J(\mathrm{C}, \mathrm{F})=12.9 \mathrm{~Hz} ; \mathrm{C}(11,12)\right) ;{ }^{19} \mathrm{~F} \mathrm{NMR}\left(376 \mathrm{MHz}, \mathrm{CDCl}_{3}, 23{ }^{\circ} \mathrm{C}\right) \delta=-$ 127.27 ppm; HR-ESI-MS: $m / z(\%): 319.0791\left(100[M+\mathrm{H}]^{+}\right.$calcd for $\left.\mathrm{C}_{18} \mathrm{H}_{9} \mathrm{~F}_{2} \mathrm{~N}_{4}{ }^{+}: 319.0790\right)$.

\subsubsection{Tetraquinone cavitand 10}

Following a reported procedure, ${ }^{[6]} \mathrm{K}_{2} \mathrm{CO}_{3}(2.68 \mathrm{~g}, 19.4 \mathrm{mmol})$ was added to a solution of octol 8 (2.0 g, $2.4 \mathrm{mmol})$ and 2,3-dichloronaphthoquinone (9) (2.32 g, $10.2 \mathrm{mmol})$ in dry $\left(\mathrm{CH}_{3}\right)_{2} \mathrm{SO}$ (75 mL). The mixture was vigorously stirred for $16 \mathrm{~h}$ at $50{ }^{\circ} \mathrm{C}$ and poured into $\mathrm{H}_{2} \mathrm{O}(150 \mathrm{~mL})$. The resulting precipitate was collected by filtration, washed with $\mathrm{H}_{2} \mathrm{O}(3 \times 50 \mathrm{~mL})$, dried in vacuo, and suspended in cold $\left(\mathrm{CH}_{3}\right)_{2} \mathrm{CO}(30 \mathrm{~mL})$. The solid was filtered off, washed with cold $\left(\mathrm{CH}_{3}\right)_{2} \mathrm{CO}$, and dried in vacuo to afford $10(1.8 \mathrm{~g}, 69 \%)$ as a yellow solid. ${ }^{1} \mathrm{H}$ NMR $\left(400 \mathrm{MHz}, \mathrm{CDCl}_{3}, 23\right.$ $\left.{ }^{\circ} \mathrm{C}\right): \delta=0.83(\mathrm{t}, J=6.8,12 \mathrm{H}), 1.19-1.40(\mathrm{~m}, 32 \mathrm{H}), 1.93-2.12(\mathrm{~m}, 8 \mathrm{H}), 4.19-4.30(\mathrm{~m}, 4 \mathrm{H}), 6.23$ (s, 2 H), 7.10 (s, 2 H), 7.16 (s, 2 H), 7.64 (s, 2 H), 7.69-7.77 (m, 8 H), 8.13-8.21 ppm (m, 8 H); ${ }^{13} \mathrm{C}$ NMR $\left(101 \mathrm{MHz}, \mathrm{CDCl}_{3}, 23{ }^{\circ} \mathrm{C}\right): \delta=13.97,22.54,27.10,29.14,31.60,31.67,35.53,110.59$, 119.62, 121.32, 126.00, 126.62, 126.88, 130.34, 130.62, 132.33, 133.74, 134.32, 134.87, 138.87, $147.81,150.96,151.60,179.70,181.42 \mathrm{ppm}$.

\subsubsection{Diquinone tetrol 11}

Following a reported procedure, ${ }^{[7]}$ anhydrous $\operatorname{CsF}(2.10 \mathrm{~g}, 14.0 \mathrm{mmol})$ was added to a solution of cavitand $10(1.0 \mathrm{~g}, 0.7 \mathrm{mmol})$ and catechol $(193 \mathrm{mg}, 1.75 \mathrm{mmol})$ in dry DMF at $70{ }^{\circ} \mathrm{C}$. The mixture was stirred for $40 \mathrm{~min}$ at $70{ }^{\circ} \mathrm{C}$, filtered over silica, and evaporated. $\mathrm{FC}\left(\mathrm{SiO}_{2} ; \mathrm{CH}_{2} \mathrm{Cl}_{2} \rightarrow\right.$ $\left.\mathrm{CH}_{2} \mathrm{Cl}_{2} / \mathrm{EtOAc} 8: 2\right)$ afforded $\mathbf{1 1}(280 \mathrm{mg}, 35 \%)$ as an orange solid. $R_{\mathrm{f}}=0.14\left(\mathrm{SiO}_{2} ; \mathrm{CH}_{2} \mathrm{Cl}_{2} / \mathrm{EtOAc}\right.$ 8:2); ${ }^{1} \mathrm{H}$ NMR (400 MHz, $\left.\left(\mathrm{CD}_{3}\right)_{2} \mathrm{CO}, 23{ }^{\circ} \mathrm{C}\right): \delta=0.80-0.91(\mathrm{~m}, 12 \mathrm{H}), 1.17-1.41(\mathrm{~m}, 32 \mathrm{H}), 1.88-$ $2.01(\mathrm{~m}, 4 \mathrm{H}), 2.15-2.26(\mathrm{~m}, 4 \mathrm{H}), 4.57(\mathrm{br} \mathrm{s}, 2 \mathrm{H}), 4.81(\mathrm{t}, J=7.6 \mathrm{~Hz}, 2 \mathrm{H}), 6.84(\mathrm{~s}, 4 \mathrm{H}), 7.18$ (s, $4 \mathrm{H}), 7.72-7.87$ (m, $4 \mathrm{H}), \quad 7.96-8.09$ (m, $4 \mathrm{H}), 8.34 \mathrm{ppm}$ (br s, $4 \mathrm{H}) ;{ }^{13} \mathrm{C}$ NMR (101 MHz, $\left.\left(\mathrm{CD}_{3}\right)_{2} \mathrm{CO}, 23^{\circ} \mathrm{C}\right): \delta=14.33,14.38,23.30,23.32,28.01,28.54,32.53,32.55,32.85,34.31,35.24$, $37.10,109.85,125.69,126.75,128.48,129.64,131.78,134.80,152.27,153.83,181.53 \mathrm{ppm}$, two aliphatic C-atoms signals are overlapping with $\left(\mathrm{CD}_{3}\right)_{2} \mathrm{CO}$ signals; HR-MALDI-MS: $\mathrm{m} / z(\%)$ : 1155.5220 (100 $[M+\mathrm{Na}]^{+}$calcd for $\left.\mathrm{C}_{72} \mathrm{H}_{76} \mathrm{NaO}_{12}{ }^{+}: 1155.5229\right)$. 


\subsubsection{6. ( \pm )-[(bpy $)_{2}$ (11,12-diphenoxydipyrido[3,2-a:2',3'-}

\section{c]phenazine)ruthenium(II)]bis(hexafluorophosphate) (12)}

A solution of 2 (200 mg, $0.2 \mathrm{mmol}$ ) and phenol $(56 \mathrm{mg}, 0.6 \mathrm{mmol})$ in dry DMF (40 mL) was treated with $\mathrm{Cs}_{2} \mathrm{CO}_{3}\left(376 \mathrm{mg}, 1.2 \mathrm{mmol}\right.$ ), stirred at $50{ }^{\circ} \mathrm{C}$ for $2 \mathrm{~h}$, cooled to $23{ }^{\circ} \mathrm{C}$, and filtered. Evaporation of the filtrate and $\mathrm{FC}\left(\mathrm{SiO}_{2}\right.$; acetone/sat. aq. $\mathrm{KNO}_{3}$ 9:1) gave a dichloride analogue of 12. After purification, it was re-dissolved in $\mathrm{CH}_{3} \mathrm{CN}(15 \mathrm{~mL})$, treated with $\mathrm{KPF}_{6}(368 \mathrm{mg}$, $2.0 \mathrm{mmol}$ ), stirred at $23{ }^{\circ} \mathrm{C}$ for $4 \mathrm{~h}$ under nitrogen atmosphere in the dark, and evaporated. The residue was re-dissolved in $\mathrm{CH}_{2} \mathrm{Cl}_{2}(25 \mathrm{~mL})$ and washed with $\mathrm{H}_{2} \mathrm{O}(3 \mathrm{X} 50 \mathrm{~mL})$. The organic layer was concentrated, and the solid was dried in vacuo to afford $12(222 \mathrm{mg}, 97 \%)$ as a red powder. $R_{\mathrm{f}}=0.35\left(\mathrm{SiO}_{2}\right.$; acetone/sat. aq. $\left.\mathrm{KNO}_{3} 9: 1\right) ;{ }^{1} \mathrm{H} \mathrm{NMR}\left(400 \mathrm{MHz}, \mathrm{CD}_{2} \mathrm{Cl}_{2}, 23{ }^{\circ} \mathrm{C}\right): \delta=7.29-7.35$ (m, 6 H; 2 H-C(16,18,20)), 7.38 (ddt, $J=7.9,7.1,1.1$ Hz, 2 H; 2 H-C(8')), 7.52 (ddd, $J=7.7,5.7$, 1.3 Hz, 2 H; 2 H-C(3')), 7.54-7.60 (m, 4 H: 2 H-C(17,19)), 7.63 (s, 2 H, H-C(10,13)), 7.69 (ddd, $\left.J=5.7,1.5,0.7, \mathrm{~Hz}, 2 \mathrm{H} ; 2 \mathrm{H}-\mathrm{C}\left(7^{\prime}\right)\right), 7.83$ (ddd, $\left.J=5.6,1.5,0.7, \mathrm{~Hz}, 2 \mathrm{H} ; 2 \mathrm{H}-\mathrm{C}\left(2^{\prime}\right)\right), 7.88$ (dd, $J$ $=8.3,5.4 \mathrm{~Hz}, 2 \mathrm{H} ; \mathrm{H}-\mathrm{C}(2,7)), 8.01\left(\mathrm{td}, J=7.9,1.5 \mathrm{~Hz}, 2 \mathrm{H} ; 2 \mathrm{H}-\mathrm{C}\left(9^{\prime}\right)\right), 8.09$ (dd, $J=5.5,1.3 \mathrm{~Hz}$, $2 \mathrm{H} ; \mathrm{H}-\mathrm{C}(3,6)), 8.11$ (td, $\left.J=7.9,1.5 \mathrm{~Hz}, 2 \mathrm{H} ; 2 \mathrm{H}-\mathrm{C}\left(4^{\prime}\right)\right), 8.45$ and $8.48(2 \mathrm{dt}, J=8.0,0.9 \mathrm{~Hz}, 4$ $\left.\mathrm{H} ; 2 \mathrm{H}-\mathrm{C}\left(5^{\prime}, 10^{\prime}\right)\right), 9.58(\mathrm{dd}, J=8.2,1.4 \mathrm{~Hz}, 2 \mathrm{H} ; \mathrm{H}-\mathrm{C}(1,8)) ;{ }^{13} \mathrm{C} \mathrm{NMR}\left(101 \mathrm{MHz}, \mathrm{CD}_{2} \mathrm{Cl}_{2}, 23{ }^{\circ} \mathrm{C}\right)$ : $\delta=112.45(\mathrm{C}(10,13)), 120.63(2 \mathrm{C}(16,20)), 124.23$ and 124.29 (2 C ( $\left.\left.5^{\prime}, 10^{\prime}\right)\right), 125.82(2 \mathrm{C}(18))$, $127.57(\mathrm{C}(2,7)) 128.06$ and $128.17\left(2 \mathrm{C}\left(3^{\prime}, 8^{\prime}\right)\right), 130.52$ (2 C(17,19)), 130.94 (C(8a,14b)), 133.78 $(\mathrm{C}(1,8)), 138.01$ (C(9a,13a)), 138.16 and $138.26\left(2 \mathrm{C}\left(4^{\prime}, 9^{\prime}\right)\right), 141.32(\mathrm{C}(8 \mathrm{~b}, 14 \mathrm{a})), 149.29$ $(\mathrm{C}(4 \mathrm{a}, 4 \mathrm{~b})), 151.48$ and $151.61\left(2 \mathrm{C}\left(2^{\prime}, 7^{\prime}\right)\right), 152.71(\mathrm{C}(3,6)), 154.68$ and $154.82(2 \mathrm{C}(11,15))$, 156.78 and $156.89\left(2 \mathrm{C}\left(5 \mathrm{a}^{\prime}, 10 \mathrm{a}^{\prime}\right)\right) ;{ }^{19} \mathrm{~F}$ NMR $\left(376 \mathrm{MHz}, \mathrm{CD}_{2} \mathrm{Cl}_{2}, 23{ }^{\circ} \mathrm{C}\right): \delta=-72.78 \mathrm{ppm}(\mathrm{d}$, $\left.{ }^{1} J(\mathrm{~F}, \mathrm{P})=706.6 \mathrm{~Hz} ; 2 \mathrm{PF}_{6}\right)$ ); HR-MALDI-MS: $m / z$ (\%): 1028.15275 (28), 1027.15021 (57), 1026.15195 (52), 1025.14931 (100 $\left[M-\mathrm{PF}_{6}\right]^{+}$calcd for $\mathrm{C}_{50} \mathrm{H}_{34} \mathrm{~F}_{6} \mathrm{~N}_{8} \mathrm{O}_{2} \mathrm{P}^{102} \mathrm{Ru}^{+}:$1025.14845), 1024.15031 (64), 1023.14975 (49), 1022.14996 (35), 1019.15150 (14).

\subsection{Electrochemistry}

Cyclic voltammograms (CV) and rotating-disk voltammograms (RDV) were recorded in a standard three electrode electrochemical cell using glassy carbon disk (GC) $(1 \mathrm{~mm}$ or $3 \mathrm{~mm}$ in diameter) as working electrode, $\mathrm{Pt}$ wire as counter electrode, and $\mathrm{AgCl}$ or $\mathrm{Pt}$ wire as reference electrode. Saturated $\mathrm{NBu}_{4} \mathrm{Cl}$ or $0.1 \mathrm{M} \mathrm{N}(\mathrm{Bu})_{4} \mathrm{PF}_{6}$ in $\mathrm{CH}_{2} \mathrm{Cl}_{2}, \mathrm{CH}_{3} \mathrm{CN}$, or DMF were used as a 
supporting electrolyte. Two CVs scans were taken at a scan rate of $100 \mathrm{mVs}^{-1}$ and the first and second scans are presented in the voltammograms reported. Square wave voltammograms (SWV) were taken with $25 \mathrm{mV}$ pulse amplitude, $30 \mathrm{~Hz}$ pulse frequency, and $5 \mathrm{mV}$ step increments. The cell was connected to HEKA PG390 potentiostat (HEKA, Germany) or to an Autolab PGSTAT30 potentiostat (Eco Chemie, Holland) driven by GSE software running on a personal computer. All potentials are $v s . \mathrm{Fc}^{+} / \mathrm{Fc}$ used as internal reference and are uncorrected from ohmic drop.

\subsection{Chemical Reduction of Cavitand 1}

$N, N$-dimethylformamide (99.8\%, extra dry over molecular sieves) was used as a solvent. It was degassed by freeze-pump-thaw method and then introduced in the dry box $\left(\left[\mathrm{O}_{2}\right]=<6 \mathrm{ppm},\left[\mathrm{H}_{2} \mathrm{O}\right]\right.$ $=<1 \mathrm{ppm}$ ) where all the solutions were prepared. First, two stock solutions were prepared, $\mathrm{Cp}_{2} \mathrm{Co}$ $\left(10^{-3} \mathrm{M}\right)$ and cavitand $1\left(10^{-4} \mathrm{M}\right)$, which were used to prepare the two working solutions $\left(10^{-6} \mathrm{M}\right.$ each) for cavitand 1 (without $\mathrm{Cp}_{2} \mathrm{Co}$ and with 2 equiv. of $\mathrm{Cp}_{2} \mathrm{Co}$ ). The working solutions were loaded into $1 \mathrm{~cm}$ quartz cuvettes with screw-caps to avoid percolation of oxygen and then taken out from the dry box for the immediate UV-Vis spectroscopy measurements at $T=298 \mathrm{~K}$. The solutions were kept in the dark at all time.

\subsection{Steady-State UV-Vis and Photoluminiscence Spectroscopy}

Steady-state UV-Vis spectroscopy was recorded on a Varian Cary-500 spectrometer, while Photoluminiscence (PL) spectroscopy was recorded on a Horiba Fluorolog-3 spectrometer. The measurements for both techniques were carried out at $T=298 \mathrm{~K}$ on a $1 \mathrm{~cm}$ quartz cuvette, and the solutions were equilibrated with air. $10^{-6} \mathrm{M}$ solutions in spectroscopic grade $\mathrm{CH}_{2} \mathrm{Cl}_{2}$ or DMF (cavitand 1 and wall model 12) or $15^{-6} \mathrm{M}$ solutions in spectroscopic grade $\mathrm{CH}_{3} \mathrm{CN}$ (wall 13) were used. All PL spectra were corrected, and excitation was done at $\lambda=450 \mathrm{~nm}$ (cavitand 1 and model 12) or $\lambda=445 \mathrm{~nm}($ model 4$)$.

\subsection{UV-Vis-NIR Spectroelectrochemistry}

In situ UV-Vis-NIR spectroelectrochemical measurements were performed with an optically transparent thin-layer electrochemical (OTTLE) cell equipped with a Pt minigrid working electrode and $\mathrm{CaF}_{2}$ optical windows. ${ }^{[26]} \mathrm{UV}-\mathrm{Vis}-\mathrm{NIR}$ spectroelectrochemical analyses have been 
carried out with a Zeiss MCS 601 UV-Vis-NIR diode array spectrometer. Spectrophotometric analyses of the films have been conducted using a $0.1 \mathrm{M}$ solution of $n-\mathrm{Bu}_{4} \mathrm{NPF}_{6}$ in $\mathrm{CH}_{2} \mathrm{Cl}_{2}$ or $\mathrm{CH}_{3} \mathrm{CN}$. The reference used is $\mathrm{AgCl} / \mathrm{Ag}$.

\subsection{EPR Spectroscopy}

The EPR spectrum was recorded for an argon saturated $\mathrm{CH}_{2} \mathrm{Cl}_{2}$ solution of ca. $0.5 \mathrm{mM}$ cavitand 1 at $120 \mathrm{~K}$ under in-situ irradiation with the unfiltered light of the UV-Vis Hg-Xe LC4, L8252 lamp (Hamamatsu, Japan). The X-band EPR spectrometer EMX (Bruker, Germany) equipped with the ER 4102ST Standard Resonator $\mathrm{N}_{2}$ (l) flow cryostat and the Eurotherm temperature control unit was used.

\subsection{Transient Absorption Spectroscopy}

Transient absorption experiments were performed on a LP920 KS instrument from Edinburgh Instruments using the frequency-doubled output $(532 \mathrm{~nm})$ of a Quantel Brilliant $\mathrm{Nd}^{3+}$ :YAG laser for excitation of the pulse duration of $\sim 10 \mathrm{~ns}$. The transient absorption measurements occurred by time-integration over a period of $20 \mu \mathrm{s}$. The data was time averaged over 10 scans after excitation at $532 \mathrm{~nm}$ with laser pulses of $\sim 10 \mathrm{~ns}$ width. The kinetic traces of were recorded between $320 \mathrm{~nm}$ and $750 \mathrm{~nm}$ in a time domain of $20 \mu \mathrm{s}$.

\subsection{Density Functional Theory (DFT) Calculations}

Geometry optimizations of 1-(Q) were performed using the hybrid density functional B3LYP (Becke-Lee-Young-Parr composite of exchange-correlation functional) in Gaussian 09. ${ }^{[27]}$ The

LANL2DZ basis set was used for Ru atoms and 6-31G(d) basis set for the other atoms. ${ }^{[28,29]}$ The calculations were performed on the Euler cluster at ETH Zurich.

\section{Corresponding Author}

Email: diederich@org.chem.ethz.ch

\section{Author Contributions}


The conceptualization of the project was done through discussions between J.M., O.W. and F. D. and later with V.G.-L, J.N., M.Z., and D.N. V.G.-L. synthesized and characterized the compounds, performed the DFT calculations, designed and carried out the chemical reduction and lightactivation experiments, the steady-state photophysical measurements, the corresponding data analysis and interpretation, and wrote the manuscript. J.M. contributed to the development of early synthetic procedures of cavitand 1, performed preliminary time-resolved data acquisition, and participated in data interpretation discussions. M.Z. designed and performed spectroelectrochemical and EPR measurements, and contributed to data analysis and interpretation. D.N. designed and performed the EPR measurements upon irradiation and contributed to data analysis and interpretation with the support of G.G. as advisor. M.K.-P. designed and performed the time-resolved luminescence studies. J.N. was involved in developing early synthetic procedures of cavitand $\mathbf{1}$ and preliminary time-resolved data acquisition, under the supervision of O.W. N.T. performed the X-ray crystallography and the corresponding analysis. L.R. and C.B. performed electrochemical and spectroelectrochemical studies. F. D. supervised the study. All authors discussed the results and revised the manuscript.

\section{Acknowledgments}

The authors are grateful to Dr. Michael Solar (ETH Zurich) for his assistance performing the XRay crystallographic measurements, the NMR service at ETH Zurich for their help in NMR spectroscopy, and to Dr. Bruno Bernet (ETH Zurich) for proofreading the manuscript. V.G.L. thanks Cédric Schaack and Cornelius Gropp for the training in DFT calculations. J.M. acknowledges the fellowship from the Dositeja Fund for Young Talents.

\section{Appendix A}

Supplementary data related to this article can be found at the journal page https://www.journals.elsevier.com/tetrahedron/

\section{References}


[1] Pochorovski, I.; Diederich, F. Acc. Chem. Res. 2014, 47, 2096 - 2105.

[2] Skinner, P. J.; Cheetham, A. G.; Beeby, A.; Gramlich, V.; Diederich, F. Helv. Chim. Acta 2001, 84, $2146-2153$.

[3] Moran, J. R.; Ericson, J. L.; Dalcanale, E.; Bryant, J. A.; Knobler, C. B.; Cram, D. J. J. Am. Chem. Soc. 1991, 113, $5707-5714$.

[4] Azov, V. A.; Jaun, B.; Diederich, F. Helv. Chim. Acta 2004, 87, 449 - 462.

[5] Frei, M.; Marotti, F.; Diederich, F. Chem. Commun. 2004, 0, 1362 - 1363.

[6] Pochorovski, I.; Boudon, C.; Gisselbrecht, J.-P.; Ebert, M.-O.; Schweizer, W. B.; Diederich, F. Angew. Chem. Int. Ed. 2012, 51, $262-266$.

[7] Pochorovski, I.; Ebert, M.-O.; Gisselbrecht, J.-P.; Boudon, C.; Schweizer, W. B.; Diederich, F. J. Am. Chem. Soc. 2012, 134, $14702-14705$.

[8] Pochorovski, I.; Milić, J.; Kolarski, D.; Gropp, C.; Schweizer, W. B.; Diederich, F. J. Am. Chem. Soc. 2014, 136, $3852-3858$.

[9] Saywell, A.; Bakker, A.; Mielke, J.; Kumagai, T.; Wolf, M.; García-López, V.; Chiang, P.T.; Tour, J. M.; Grill, L. ACS Nano 2016, 10, 10945 - 10952.

[10] Balzani, V.; Credi, A.; Venturi, M. Chem. Soc. Rev. 2009, 38, 1542 - 1550.

[11] Kudernac, T.; Ruangsupapichat, N.; Parschau, M.; Maciá, B.; Katsonis, N.; Harutyunyan, S. R.; Ernst, K.-H.; Feringa, B. L. Nature 2011, 479, 208 - 211.

[12] Collier, C. P.; Mattersteig, G.; Wong, E. W.; Luo, Y.; Beverly, K.; Sampaio, J.; Raymo, F. M.; Stoddart, J. F.; Heath, J. R. Science 2000, 289, 1172 - 1175.

[13] Milić, J.; Zalibera, M.; Talaat, D.; Nomrowski, J.; Trapp, N.; Ruhlmann, L.; Boudon, C.; Wenger, O. S.; Savitsky, A.; Lubitz, W.; Gescheidt, G.; Diederich, F. J. Phys. Chem. Lett. 2016, 7, $2470-2477$.

[14] Milić, J.; Zalibera, M.; Pochorovski, I.; Trapp, N.; Nomrowski, J.; Neschadin, D.; Ruhlmann, L.; Boudon, C.; Wenger, O. S.; Savitsky, A.; Lubitz, W.; Diederich, F. Chem. Eur. J. 2018, $24,1431-1440$.

[15] Goulle, V.; Harriman, A.; Lehn, J.-M. J. Chem. Soc., Chem. Commun. 1993, 0, 1034 - 1036

[16] Hankache, J.; Wenger, O. Phys. Chem. Chem. Phys. 2012, 14, 2685 - 2692. 
[17] Olson, E. J. C.; Hu, D.; Hörmann, A.; Jonkman, A. M.; Arkin, M. R.; Stemp, E. D. A.; Barton, J. K.; Barbara, P. F. J. Am. Chem. Soc. 1997, 119, 11458 - 11467.

[18] Sun, Y.; Lutterman, D. A.; Turro, C. Inorg. Chem. 2008, 47, 6427 - 6434.

[19] Dupureur, C. M.; Barton, J. K. Inorg. Chem. 1997, 36, 33 - 43.

[20] Hankache, J.; Wenger, O. S. Phys. Chem. Chem. Phys. 2012, 14, 2685 - 2692.

[21] Nomrowski, J.; Wegner, O. S. Inorg. Chem. 2015, 54, 3680 - 3687.

[22] Juris, A.; Balzani, V. Helv. Chim. Acta 1981, 64, 2175 - 2182.

[23] Michaelson, H. B. J. App. Phys. 1977, 48, 429 - 4733.

[24] Calvo, R.; Abresch, E. C.; Bittl, R.; Feher, G.; Hofbauer, W.; Isaacson, R. A.; Lubitz, W.; Okamura, M. Y.; Paddick, M. L. J. Am. Chem. Soc. 2000, 122, 7327 - 7341.

[25] Vân Anh, N.; Williams, R. M. Photochem. Photobiol. Sci. 2012, 11, 957 - 961.

[26] Krejčík, M.; Daněk, M.; Hartl, F. J. Electroanal. Chem. 1991, 317, 179 - 187.

[27] Frisch, M. J.; Trucks, G. W.; Schlegel, H. B.; Scuseria, G. E.; Robb, M. A.; Cheeseman, J. R.; Scalmani, G.; Barone, V.; Mennucci, B.; Petersson, G. A.; Nakatsuji, H.; Caricato, M.; Li, X.; Hratchian, H. P.; Izmaylov, A. F.; Bloino, J.; Zheng, G.; Sonnenberg, J. L.; Hada, M.; Ehara, M.; Toyota, K.; Fukuda, R.; Hasegawa, J; Ishida, M.; Nakajima, T.; Honda, Y.; Kitao, O.; Nakai, H.; Vreven, T.; Montgomery, Jr., J. A.; Peralta, J. E.; Ogliaro, F.; Bearpark, M.; Heyd, J. J.; Brothers, E.; Kudin, K. N.; Staroverov, V. N.; Keith, T.; Kobayashi, R.; Normand, Raghavachari, K.; Rendell, A.; Burant, J. C.; Iyengar, S. S.; Tomasi, J.; Cossi, M.; Rega, N.; Millam, J. M.; Klene, M.; Knox, J. E.; Cross, J. B.; Bakken, V.; Adamo, C.; Jaramillo, J.; Gomperts, R.; Stratmann, R. E.; Yazyev, O.; Austin, A. J.; Cammi, R.; Pomelli, C.; Ochterski, J. W.; Martin, R. L.; Morokuma, K.; Zakrzewski, V. G.; Voth, G. A.; Salvador, P.; Dannenberg, J. J.; Dapprich, S.; Daniels, A. D.; Farkas, O.; Foresman, J. B.; Ortiz, J. V.; Cioslowski, J.; Fox, D. J. Gaussian 09, Revision D.01, Gaussian, Inc., Wallingford CT, 2013.

[28] Hay, P. J.; Wadt, W.R. J. Chem Phys. 1985, 82, 270 - 283.

[29] Wadt, W.R.; Hay, P. J. J. Chem Phys. 1985, 82, $284-298$. 